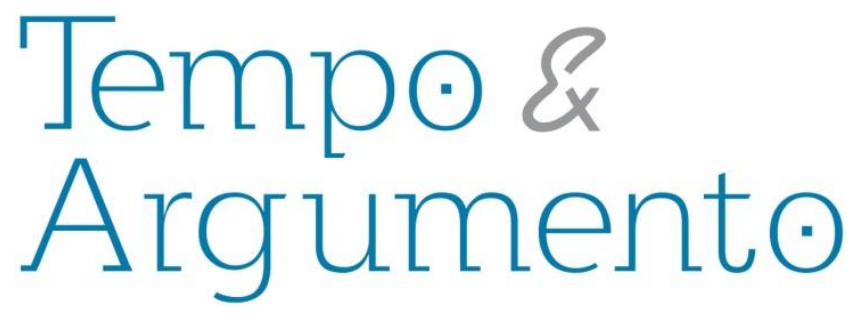

\title{
Aniversários do golpe de 1964: debates historiográficos, implicações políticas ${ }^{1}$
}

\section{Resumo}

As datas de aniversários "redondos" do golpe de 1964 foram momentos de efervescência de controvérsias públicas e acadêmicas acerca da ditadura militar. Esse artigo discute algumas delas, em torno dos seguintes temas: o caráter do golpe, a natureza do regime, a relação da sociedade civil com a ditadura, o papel da luta armada e a periodização da ditadura. O propósito é de situar historicamente o surgimento e desdobramento de cada um desses debates, além de problematizar suas repercussões políticas. Constata-se a longevidade e renovação de algumas das discussões, bem como o crescimento significativo do interesse acadêmico e público sobre a ditadura militar e seus legados.

Palavras-chave: Ditadura. Golpe de 1964.

Historiografia. História do Tempo Presente. Datas

Comemorativas.

\section{Mariana Joffily}

Doutora em História pela Universidade de São Paulo. Professora do Departamento de História e do Programa de PósGraduação em História da Universidade do Estado de Santa Catarina. Florianópolis - SC - BRASIL mariana.joffily@gmail.com

\section{Para citar este artigo:}

JOFFILY, Mariana. Aniversários do golpe de 1964: debates historiográficos, implicações políticas.

Tempo e Argumento, Florianópolis, v. 10, n. 23, p. 204 - 251, jan./mar. 2018.

\section{DOI: $10.5965 / 2175180310232018204$}

http://dx.doi.org/10.5965/2175180310232018204

\footnotetext{
${ }^{1}$ Esse texto foi elaborado para a mesa-redonda Ditaduras do Cone Sul: debates historiográficos e implicações políticas, do III Simpósio Internacional História do Tempo Presente, realizado na UDESC em outubro de 2017, da qual participaram igualmente Marina Franco e Verónica Valdivia. Registro meu agradecimento a Nashla Dahás pela interlocução e a Daniel Saraiva pela pesquisa de artigos na imprensa. Esse artigo faz parte de um projeto financiado pelo CNPq.
} 


\title{
Anniversary of the 1964 coup: historiographical debates, political implications
}

\begin{abstract}
The "round" anniversary dates of the coup of 1964 were effervescent moments of public and academic controversies about the military dictatorship. This article discusses some of them: the character of the coup, the nature of the regime, the relationship between civil society and dictatorship, the role of armed struggle and the periodization of dictatorship. The purpose is to situate historically the emergence and unfolding of each of these debates, in addition to problematizing its political repercussions. We note the longevity and renewal of some of the discussions as well as the significant growth of academic and public interest on the military dictatorship and its legacies.
\end{abstract}

Keywords: Dictatorship, 1964 Coup, Historiography, History of the Present Time, Significant Dates.

Os aniversários "redondos" de eventos políticos importantes, como os 50 anos do golpe civil-militar no Brasil, são momentos de ativação da memória que conclamam a debates, "des-comemorações" e balanços historiográficos. Atividades como exposições, lançamentos de filmes e documentários, mesas-redondas, publicação de edições especiais de revistas, encartes especiais de jornais, enfim, uma multiplicidade de eventos que recolocam o passado dentro do debate público. Como bem situa Elizabeth Jelin:

Se trata de fechas en que el pasado se hace presente en rituales públicos, en que se activan sentimientos y se interrogan sentidos, en que se construyen y reconstruyen las memorias del pasado. Son momentos en que diferentes actores de cada país eligen para expresar y confrontar, en el escenario nacional, los sentidos que otorgan a los quiebres institucionales que unos impulsaron y otro/a sufrieron (JELÍN, 2002). 
A atenção pública ao tema da ditadura, refletida na produção historiográfica, teve um crescimento exponencial nas últimas décadas. Em 1994, foram relativamente pouco numerosas as expressões voltadas aos 30 anos do golpe: ainda não se completara uma década do final da ditadura militar e a experiência do autoritarismo, ainda recente, era matéria a superar mais do que a indagar. O ano de 2004 testemunhou um interesse crescente da sociedade - academia, movimentos sociais, mídia - sobre o tema e um debate ativo entre os historiadores, partindo de diferentes perspectivas analíticas para interpretar o período. Em encarte especial sobre março de 64 n'O Estado de S.Paulo, um jornalista notava a "diferença gritante" entre a quantidade de livros publicados naquele ano, com o que havia saído dez anos antes (PIZA, 2004). Foi no cinquentenário do golpe, em 2014, porém, que houve uma verdadeira erupção de sentidos múltiplos e conflitantes sobre o passado autoritário. Não por acaso: a recente lei de Acesso à Informação franqueou acesso a um enorme contingente documental sobre o período; a atuação da Comissão Nacional da Verdade (CNV), amplificada por comissões estaduais, municipais e institucionais e a presidência de uma ex-guerrilheira fizeram com que o interesse no tema chegasse a um ápice dificilmente reproduzível.

Pensando essas datas comemorativas como momentos que condensaram debates iniciados anteriormente, proponho, nesse artigo, estabelecer um quadro em grandes linhas de interpretações historiográficas sobre a ditadura militar, tendo em vista sua evolução no tempo e implicações políticas na esfera pública² ${ }^{2}$ Busco, com isso historicizar a emergência de algumas discussões, situá-las no contexto vivido pelo país e, sobretudo, pensar nos transbordamentos públicos dos debates historiográficos. No Brasil, os estudos no campo da História do Tempo Presente têm produzido trabalhos sobretudo na área da memória ${ }^{3}$. Pretendo, também, explorar outro domínio característico desse campo: as repercussões políticas das discussões acadêmicas no debate público.

O alargamento do debate acadêmico sobre a ditadura para o espaço público é um fenômeno relativamente novo, uma vez que o interesse pelo período cresceu apenas

\footnotetext{
${ }^{2}$ Entre os levantamentos historiográficos sobre a ditadura e alguns de seus debates, destaco (FICO, 2004, 2017; BADARÓ, 2008; NAPOLITANO, 2011 e 2016; MELO, 2014; D’ARAÚJO, 2015)

3 Para citar apenas alguns trabalhos nessa direção (MARTINS FILHO, 2003; ROLLEMBERG, 2006; MOTTA, 2013; NAPOLITANO, 2015).
} 
recentemente. Como bem notou Napolitano (2015), se os vencidos foram vitoriosos nas batalhas da memória social sobre a ditadura, isso não se traduziu na construção de uma sociedade amplamente democrática e receptiva aos direitos humanos. A convivência de uma memória de rechaço à ditadura e ao autoritarismo por ela implementada com uma disparidade brutal de distribuição de renda, crescimento exponencial da população carcerária e prática quotidiana de assassinato de jovens negros e mestiços nas periferias, ajuda a explicar a pouca adesão popular a uma temática em muitos aspectos restrita a setores de classe média intelectualizada.

Por outro lado, no campo acadêmico, é interessante observar que os pilares dos principais debates historiográficos foram estabelecidos muito precocemente. Embora me concentre nos períodos comemorativos, buscarei historicizar alguns desses debates, abordando polêmicas em torno de cinco questões: o caráter do golpe, a natureza do regime, a relação da sociedade civil com a ditadura, o papel da luta armada e a periodização da ditadura.

\section{Anos 1980: primeiros debates}

Interpretações sobre o golpe e a ditadura foram sendo construídas por jornalistas e cientistas políticos já nos primeiros anos da ditadura, conforme os acontecimentos se desenrolavam ${ }^{4}$. Gostaria de me deter em três obras produzidas no início dos anos 1980, em meio à batalha de memórias travada pela publicação de relatos pessoais de ex-presos políticos e narrativas de militares envolvidos na ditadura (MARTINS FILHO, 2003). Foram selecionadas por terem sido escritas em um período no qual a ditadura estava chegando ao seu fim, o que permitiu a realização de um esforço analítico em perspectiva mais dilatada, por serem amparadas por ampla documentação e por terem tido significativo impacto na historiografia posterior. Trata-se de 1964, A conquista do Estado, de René Armand Dreifuss (1981), Estado e oposição no Brasil, de Maria Helena Moreira Alves (1984) e Brasil: nunca mais (1985), concebido com apoio da Arquidiocese de São Paulo. Essas obras adotaram o ponto de vista construído nos anos 1970 pelos setores de esquerda e teorizados por autores como Florestan Fernandes e Fernando Henrique Cardoso,

\footnotetext{
${ }^{4}$ Para alguns exemplos, ver (FICO, 2004a, p. 23; NAPOLITANO, 2016, p. 1).
} 
segundo o qual o golpe e a ditadura teriam sido resultado, na esfera econômica, do esgotamento do modelo de industrialização por substituição de importações e anseio da elite empresarial e financeira em associar-se ao capital externo e, nas esferas política e social, pela crise do pacto populista - produzida pela aspiração de setores populares a reformas que permitissem maior inclusão social. A nova fase de desenvolvimento do capitalismo exigiria uma associação mais aprofundada das elites nacionais com o capital transnacional, que por sua vez requeria transformações nos mecanismos de acumulação incompatíveis com as crescentes aspirações de setores populares pelas reformas de base.

Com a publicação de 1964, A conquista do Estado, iniciou-se um debate em torno do caráter do golpe e da ditadura que assumiria diferentes contornos ao longo do tempo, mostrando surpreendente longevidade. Nessa obra, o cientista político Armand Dreifuss confronta autores como o estadunidense Alfred Stepan (1971), que considerou como o aspecto mais notável de 1964 o fato de os militares terem ocupado o poder. Diferente das intervenções anteriores, quando haviam exercido uma espécie de poder "moderador", após o golpe teriam decidido permanecer na condução política do país, por sentirem-se aptos a desempenhar essa função ${ }^{5}$. Dreifuss defende que o golpe foi fruto da ação da classe dirigente, composta pela burguesia nacional articulada com os interesses do bloco multinacional e associado. Teria resultado de uma campanha - detalhadamente descrita e abundantemente documentada -, movida pela maioria das classes dominantes para a tomada do poder, bloqueando a via nacional-reformista e ancorando "firmemente 0 Estado brasileiro à estratégia global das corporações multinacionais" (DREIFUSS, 1981, p. 38).

O golpe é classificado como “civil-militar”, uma vez que teria sido arquitetado por setores dominantes do mundo civil, articulados com figuras-chave do setor militar, uns e outros integrantes do complexo formado pelo Instituto de Pesquisas e Estudos Sociais (IPES) e Instituto Brasileiro de Ação Democrática (IBAD). Na obra de Dreifuss, os militares aparecem como sócios menores em um esforço plural, do qual participaram figuras públicas estadunidenses, políticos de partidos tradicionais e governadores dos Estados

\footnotetext{
${ }^{5}$ Carlos Fico (2017) notou recentemente a semelhança - inclusive no título - entre a tese de Stepan e o ensaio apresentado por Robert W. Dean, conselheiro da embaixada dos Estados Unidos em Brasília, ao War College, provavelmente desenvolvendo uma interpretação do embaixador estadunidense Lincoln Gordon.
} 

próprios militares" (DREIFUSS, 1981, p. 362).

Quanto ao regime implementado após 1964, Dreifuss assinala a importância da presença civil em ministérios e órgãos administrativos, configurada, em sua maioria, por empresários e não tecnocratas. Para o autor, os principais cargos estratégicos de tomada de decisão foram ocupados por membros do complexo IPES/IBAD ou industriais e banqueiros alinhados com seu projeto. E, mais significativo ainda, aponta para a "congruência das reformas administrativas econômicas e política pós-1964 com as propostas de reformas aventadas pelos grupos de Estudo e Doutrina do IPES, que forneceu as diretrizes e orientações para reformas estruturais e mudanças organizacionais da administração", servindo aos interesses dos industriais e banqueiros (DREIFUSS, 1981, p. 417). Embora considere que a modernização da estrutura social e econômica do Estado imposta pelo IPES tenha sido conduzida pela classe empresarial em benefício próprio, Dreifuss reconhece discretamente que esse grupo perdeu sua hegemonia no período posterior ao Al-5 e teria voltado a predominar mais tarde, durante a presidência do general Ernesto Geisel (DREIFUSS, 1981, p. 454-5). Suas análises centramse prioritariamente nos anos que antecederam o golpe, porém há uma clara tese sobre o que seria o caráter da ditadura militar em termos de projeto para o país.

Maria Victória Benevides, em resenha sobre a obra $(2003)^{6}$, adverte que os "rumos militares e estatizantes pós 64" (BENEVIDES, 2003, p. 257) frustrariam muitos empresários liberais e que a obra de Dreifuss subestimava o papel dos militares: "A ideia autoritária da necessidade de um Estado forte sempre esteve presente nas formulações dos militares, atentos às questões de soberania, do desenvolvimento com segurança nacional". Lembra, ainda, que o próprio autor apontava para um maior protagonismo militar, ao mencionar que "os industriais e tecno-empresários ligados à estrutura multinacional transmitiam e recebiam treinamento em administração pública e objetivos empresariais na ESG". Contudo, teria se furtado a inserir esse importante elemento em sua análise.

\footnotetext{
${ }^{6}$ Resenha publicada em 1981, reproduzida em 2003 pela revista Lua Nova e mencionada por MELO, 2014.
} 
Outra corrente importante de interpretação da ditadura no início dos anos 1980 foi aquela que atribuiu grande relevância à Doutrina de Segurança Nacional (DSN). Segundo essa perspectiva, apresentada pela cientista política Maria Helena Moreira Alves (1984), a ditadura correspondeu às diversas fases de implementação da DSN, cujos principais componentes seriam a teoria da segurança interna, o modelo de desenvolvimento econômico e os objetivos nacionais permanentes. Sua aplicação, entretanto, teria sofrido reveses em virtude de reações de setores organizados da oposição. Essa dialética entre a aplicação do projeto de Segurança Nacional e as reações em contrário da oposição organizada teria sido responsável pela dinâmica do período, com variações entre momentos de institucionalização e repressão e outros de liberalização: "Formas específicas de controle tiveram de ser criadas em resposta a desafios apresentados pela sociedade civil, pois a oposição desenvolveu-se em grupos sociais no Judiciário, no Legislativo e até mesmo em meio ao próprio 'público interno' militar" (ALVES, 1984, p. 375).

A autora integra as teses de Dreifuss e de Alfred Stepan como complementares, mais do que concorrentes:

\begin{abstract}
A tomada do poder de Estado foi precedida de uma bem orquestrada política de desestabilização que envolveu corporações multinacionais, o capital brasileiro associado-dependente, o governo dos Estados Unidos e militares brasileiros - em especial um grupo de oficiais da Escola Superior de Guerra (ESG) (ALVES, 1984, p. 27).
\end{abstract}

Lembra que a instituição militar, que também contava em seus quadros com civis pertencentes à elite nacional, foi a responsável pela elaboração da doutrina que deu sustentação ideológica e programática à ditadura militar (ALVES, 1984, p. 28)7.

Uma terceira visão influente foi aquela produzida pela obra Brasil: nunca mais (BNM), realizada por uma equipe multidisciplinar de ativistas políticos (ARQUIDIOCESE

\footnotetext{
7 Em resenha publicada na Revista de História, ainda em 1984, Rosa Maria Godoy Silveira destaca que a obra teria derrubado os postulados teórico-metodológicos segundo os quais não se podia fazer uma análise histórica do passado recente e menos ainda com envolvimento político por parte do autor: "nos parece que sua ampla militância política em comunidades de base, sindicatos e grupos de direitos humanos, longe de deformar a obra pela parcialidade, permitiu-lhe, ao contrário, a necessária familiaridade com o objeto de estudo e com os instrumentos essenciais à consecução da pesquisa” (Silveira, 1984, p. 1887).
} 
impasse que levou ao golpe é também descrito como fruto de transformações de grande porte: “desenvolvimento econômico e mudanças sociais que gerariam a necessidade de modificações profundas no edifício social brasileiro" (ARQUIDIOCESE DE SÃO PAULO, 1985, p. 56). A ruptura de 1964, porém, estaria também inserida na tradição de intervenção na política por parte dos militares, seja em golpes, seja na supressão de movimentos rebeldes. A efervescência dos movimentos sociais do início dos anos 1960 é contraposta à elevada inflação, à pregação da direita anticomunista junto às classes médias, à oposição do Congresso às reformas propostas pelo governo João Goulart e à colaboração entre a CIA, a diplomacia estadunidense, o complexo IPES/IBAD e os militares. Como nas obras anteriores, o golpe de 1964 é visto como fruto de uma coalizão civil-militar, que havia efetuado um elaborado trabalho prévio de convencimento político:

Praticamente toda a classe média e setores importantes dos trabalhadores rurais e urbanos estavam ganhos pela propaganda anticomunista. Seus principais veículos foram os organismos financiados pelos Estados Unidos, o Partido Social Democrático (PSD), a União Democrática Nacional (UDN) e a Igreja Católica, especialmente sua hierarquia, que se une à agitação contra o governo, amparada pela grande imprensa, e enseja as célebres "marchas da família com Deus, pela liberdade” (ARQUIDIOCESE DE SÃO PAULO, 1985, p. 59).

No entanto, ao longo do livro, baseado em documentos oriundos do Supremo Tribunal Militar, os militares têm papel protagonista, como não poderia deixar de ser em uma obra cujo principal objetivo era denunciar a atuação da engrenagem repressiva criada no período. Se o livro de Maria Helena Moreira Alves apontou de forma consistente o aparato de leis autoritárias e órgãos de informação e repressão criados pela ditadura, o BNM deu um passo decisivo - tanto no espaço acadêmico, quanto político no sentido de demonstrar o caráter sistemático e estruturado do uso da tortura e da violência no funcionamento do aparato repressivo. 
Coincidiam essas diferentes correntes interpretativas em dois pontos: na denúncia do papel das elites na imposição e institucionalização de um modelo autoritário e excludente e na visão da ditadura como um projeto bem definido de transformação social de cima para baixo. No processo de passagem da presidência militar para a civil, ecoavam as advertências dos autores sobre as profundas marcas que a modernização conservadora imprimira na reestruturação da sociedade brasileira.

No plano político do início dos anos 1980, negociava-se a transição para a democracia sob a tutela dos militares, cujo discurso sustentava-se no argumento de terem salvado o país do comunismo. Por outro lado, instalava-se uma contradição identificada com acuidade por Marcos Napolitano (2015): uma memória social construída por setores liberais que contribuíram a arquitetar o golpe e a ditadura, mas que foram paulatinamente afastando-se de seu núcleo de poder, e incorporaram elementos da interpretação de setores oposicionistas da esquerda não armada. Conviveram assim, nesse complexo processo: 1. uma memória crítica à ditadura, difundida pela grande imprensa, pelo discurso dos principais partidos políticos de centro e de esquerda, mas também por parte dos movimentos sociais, que tendia a concentrar o grosso da responsabilidade do arbítrio no setor militar, subdimensionando o papel das elites civis; 2. uma transição democrática feita por cima, a despeito da mobilização popular, com a participação de políticos da base de sustentação da ditadura na transição; e 3. os legados autoritários da ditadura militar.

A transição brasileira foi marcada pela massiva campanha das Diretas Já (1984), cuja derrota foi em certa medida ofuscada pelas esperanças suscitadas em torno da Constituinte (1987). A elaboração da nova Carta Magna mobilizou diversas agendas dos setores de esquerda, refletindo a renovação do campo com a emergência de grupos com reivindicações diferenciadas (feministas, negros, homossexuais, ambientalistas) e de setores de base que surgiram nos anos 1970 e 1980 (novo sindicalismo, clubes de mães, movimentos de favelas). Nesse contexto de alargamento das pautas, gestou-se um importante questionamento historiográfico a respeito da atuação da esquerda armada e de suas relações com as camadas da sociedade que pretendia representar e liderar. É importante notar que, diferentemente da versão argentina, o Nunca mais brasileiro não 

dos grupos clandestinos que fizeram a opção pelas armas foi aquela apresentada tanto por Alves, quanto pelo BNM: a escolha da radicalização como uma estratégia que vinha sendo discutida desde 1967, mas que só teria sido efetivamente implementada como resposta ao fechamento dos canais legais de atuação política, com a edição do Ato Institucional $\mathrm{n}^{0} 5$ (Al-5), em dezembro de 1968. Ecoando as reflexões de parte da militância de esquerda, Alves considera que, se a contestação armada foi fruto de um fechamento do regime, por sua vez gerou um reforço sem precedentes da repressão política, contribuindo involuntariamente para seu próprio aniquilamento: “A luta armada, por sua vez, fortaleceu no Estado de Segurança Nacional os setores voltados para a defesa da Segurança Interna. Eles efetivamente se valeram do espaço de que dispunham para implantar um formidável aparato de repressão e institucionalizar a estratégia de controle pelo terror" (ALVES, 1984, p. 166).

Um esforço mais sistemático de reflexão sobre as esquerdas iniciou-se no final dos anos 1980, produzindo interpretações ancoradas na experiência pessoal dos autores e embasadas em pesquisa documental e entrevistas. Adotando uma linha de viés marxista, porém com diferenças significativas em relação à análise de Dreifuss, Jacob Gorender considera que no período que antecedeu à intervenção, houve uma ameaça real à classe dominante brasileira e ao imperialismo, fruto de uma mobilização sem precedentes dos trabalhadores e movimentos sociais. O autor fala em "auge da luta de classes", que teria ameaçado de fato "a estabilidade institucional da ordem burguesa sob os aspectos do direito de propriedade e da força coercitiva do Estado." Diante do que teria se configurado como uma "situação pré-revolucionária", o caráter do golpe deve ser definido como “contra-revolucionário preventivo" (GORENDER, 1998, p. 73)

\footnotetext{
${ }^{8}$ No volume publicado em 1987, Perfil dos atingidos, há uma caracterização das diferentes organizações de esquerda que foram alvo da repressão política.

${ }^{9}$ A edição original é de 1987.
} 
Para o autor, as esquerdas, porém não estiveram à altura do desafio histórico, tendo sido incapazes de aproveitar o momentum, inviabilizando o golpe e promovendo as mudanças estruturais que reclamava. A luta armada teria sido uma reação "retardada", articulando-se apenas após o golpe e sendo de fato deflagrada em 1968, quando o poder já estava organizado sob a égide das novas diretrizes e as forças armadas preparadas para o combate interno: "Em condições desfavoráveis, cada vez mais distanciada da classe operária, do campesinato e das camadas médias urbanas, a esquerda radical não podia deixar de adotar a concepção da violência incondicionada para justificar a luta armada imediata" (GORENDER, 1998, p. 286).

A roda-viva em que se envolveu a militância armada é descrita em traços rápidos por Gorender: repressão preparada e coordenada; clandestinidade que conduzia a ações armadas para sustentá-la financeiramente; prisão de quadros que exigiam rápida substituição. Também não passou desapercebido ao autor o processo de isolamento social dos grupos que se colocavam como a vanguarda dos setores populares que se propunham a liderar, provocado pela violência das ações armadas, pelo medo da repressão política e pelos efeitos do crescimento econômico, que trouxeram certo apoio popular ao regime.

A perspectiva de Gorender difere daquela de Dreifuss ao insistir na progressiva militarização do Estado, como elemento político mais "peculiar" do período, e na indeterminação e incertezas, inclusive dentro dos núcleos dominantes, dos rumos políticos do pós-golpe:

Como já afirmei, a conspiração direitista pré-64 partiu de diversos núcleos e nunca chegou a ter comando plenamente unificado. Se, no primeiro momento, houve acordo geral das frações da classe dominante na entrega do poder às Forças Armadas, a ideia de um regime militar duradouro não estava nos planos de importantes conspiradores, em particular os candidatos à presidência da República. Tampouco o embaixador Gordon, conforme revela sua correspondência diplomática, julgou que aquela fosse a melhor solução (GORENDER, 1998, p. 78).

Explicação muito distinta foi formulada por outro ex-militante, porém já dentro da academia, segundo a qual a derrota da esquerda não teria sido fruto de seus equívocos 
ou fragilidades, mas de seus acertos. Para Daniel Aarão Reis (1990), as organizações da esquerda armada estariam convenientemente preparadas para uma situação revolucionária, mas "a revolução faltou ao encontro", ou seja, a dinâmica dos movimentos sociais não apontou para o rompimento radical com a ordem estabelecida. $\mathrm{O}$ isolamento das organizações em relação à sociedade e aos setores populares, apontado por Gorender, seria para Aarão Reis produto do caráter vanguardista da esquerda armada e de seus mecanismos de manutenção de coesão interna (apego a princípios, mais do que adaptação às dinâmicas da sociedade), uma vez que o papel da vanguarda é estar à frente, não par i passu. O apego aos princípios, a autoimagem de liderança esclarecida, a hierarquização, teriam provocado um afastamento das organizações em relação à sociedade e uma incompreensão, por parte da militância, do que era dinâmica social concreta. Sua tese, polêmica, dialogava com os intensos debates sobre a luta revolucionária travados pelas esquerdas ainda nos anos 1970, seja ao longo do enfrentamento com a repressão política, seja no exílio.

A publicação de A revolução faltou ao encontro, em 1990, praticamente coincidiu com a queda do Muro de Berlim (1989). O evento cristalizou uma mudança considerável do ponto de vista do horizonte de expectativas da esquerda mundial, marcando o fim de uma era em que a experiência revolucionária socialista representou uma alternativa não apenas viável, mas pensada como inevitável, dado o estado de desenvolvimento das contradições sociais no seio do capitalismo, sobretudo nos países do chamado terceiro mundo.

Outro marco interpretativo, já sem ligação direta com a militância dos anos 1960 e 1970, foi produzido justamente em um intento de "desvendar o significado e as raízes sociais da luta dos grupos de esquerda, especialmente os armados, entre 1964 e 1974" (RIDENTI, 1993, p. 15). Com efeito, o universo ideológico das lutas da esquerda parecia, já no final dos anos 1980, completamente destituído de lógica: após a chamada "década perdida”, proclamava-se a vitória final do capitalismo e a retórica revolucionária marxistaleninista-guevarista ficou relegada a mero episódio histórico. Marcelo Ridenti problematiza a tese, defendida por outros autores, da opção pelas armas como resultado do fechamento dos canais institucionais de participação política, promovido pelo golpe 
de 1964 e pelo endurecimento do regime com o Al-5 em 1968. Argumenta que essa explicação nega a luta de classes como fundamento da sociedade capitalista e pensa a revolução como resultado de uma disfunção das instituições sociais:

As lutas de classes, de que as organizações de esquerda foram uma das expressões, não podem ser explicadas pela ação repressiva do regime civil-militar, nem pelas falhas das instituições desse regime, ou das anteriores ao golpe de 64 , senão teríamos subjacente a ideia de que, se não houvesse falhas nas instituições, não haveria luta de classes (RIDENTI, 1993, p. 62).

O autor, como Daniel Aarão Reis já havia feito, lembra que os projetos da esquerda - armada ou não - não apenas eram anteriores ao golpe de 1964, boa parte deles influenciados pela Revolução Cubana, como transcendiam em muito a resistência ao regime autoritário, propondo profunda transformação da sociedade (RIDENTI, 1993, p. 63). Porém, tem o cuidado de diferenciar o que foi projeto e o que foi prática dessas organizações clandestinas de esquerda. Argumenta que "O fato é que se instalou um regime militar no Brasil, e naquela conjuntura a ação dos grupos armados tomou a forma de resistência contra a ditadura, mesmo que o projeto guerrilheiro fosse anterior a ela e não pretendesse ser só resistência [...]", sem deixar de reconhecer que tratava-se de "Uma resistência armada que não implicava necessariamente a ideia de redemocratização, mas, sobretudo a de revolução" (RIDENTI, 1993, p. 64).

Ridenti debate com uma bibliografia e uma memória - de ex-guerrilheiros ${ }^{10}$ - que, em sintonia com o processo de democratização e com as reflexões oriundas da experiência do exílio na Europa e nos Estados Unidos, abolia a luta armada como opção legítima de atuação política. Dialoga também com uma crítica à opção guerrilheira formulada ainda no período, no próprio campo das esquerdas, em especial pelo Partido Comunista Brasileiro, que acreditava que as ações armadas "retroalimentavam a violência repressiva do regime, além de isolar os guerrilheiros da sociedade civil" (NAPOLITANO, 2015, p. 24).

\footnotetext{
${ }^{10}$ Há que se tomar o cuidado de não homogeneizar a memória militante sobre o período. A conclusão a que chega Ridenti ampara-se no relato de ex-guerrilheiros que recuperam o projeto revolucionário das organizações da esquerda clandestina.
} 
Nesse sentido, para pensar uma História do Tempo Presente na América Latina, talvez a experiência histórica mais marcante referente a uma ruptura radical com o passado - em termos de imaginação política do possível - tenha sido não o advento das ditaduras, mas seu período imediatamente posterior. Com a derrota do ciclo de luta armada dos anos 1960 a 1980, no qual ficaram enterradas as opções revolucionárias, a democracia foi ressignificada como único horizonte desejável de mudanças, mesmo pela esquerda, e a retórica revolucionária foi substituída pela dos direitos humanos.

Assim, é notável que ao retomar o sentido mais amplo da luta das organizações da esquerda armada, Ridenti tenha tido o cuidado tanto acadêmico quanto político de matizar a responsabilidade desse setor pela repressão perpetrada pelos órgãos de segurança:

Fica, pois, difícil atribuir apenas às esquerdas armadas urbanas todo o peso da derrota das "forças progressistas". Elas eram tão-somente a parte mais extremada da oposição e dos movimentos sociais do período, todos eles neutralizados pelo regime civil-militar estabelecido, que para tanto lançou mão, sempre que julgava necessário, de intensa repressão (RIDENTI, 1993, p. 67).

Evitou, assim, corroborar com o argumento central da memória militar, estabelecido antes mesmo de ser memória, como fundamento legitimador da violência do Estado, de que o aparato repressivo fora montado e atuara para defender a democracia. Ademais, Ridenti positiva a atuação da esquerda armada como legado de uma geração que, apesar de distanciada das bases sociais que queria emancipar e derrotada, opôs algum tipo de resistência a um regime autoritário.

\section{4: 30 anos do golpe}

A década de 1990, aberta sob o signo da Constituição de 1988, foi um período de reacomodação das forças políticas brasileiras, com a convivência de atores que haviam servido de sustentação à ditadura, oposicionistas célebres que se reintegraram à vida política brasileira após a Lei de Anistia (1979) e representantes de novos movimentos sociais, gestados nos anos finais do período autoritário. Ficou marcada, já em seu início, 
pelo escândalo de corrupção no qual se envolveu o presidente da República, Fernando Collor de Mello e seu posterior impeachment, exigido por um amplo movimento da sociedade - reunindo entidades estudantis, sindicatos, grande imprensa e parte considerável dos partidos políticos. Em plano mais abrangente, o aniversário coincidiu com a onda neoliberal que varreu o continente e com uma guinada da esquerda nacional e internacional no sentido de valorizar a democracia como um "valor em si mesmo" (TOLEDO, 2014, p. 27). A derrocada do chamado socialismo real e a nova perspectiva política da esquerda criaram uma espécie de fosso em relação às experiências dos grupos armados clandestinos, que denunciavam os estreitos limites da democracia liberal e tinham a revolução em sua agenda política. Nesse conturbado contexto político, os trinta anos do golpe tiveram alguma ressonância, tanto no mundo acadêmico, quanto no mercado editorial, porém nada comparável ao que ocorreria nas décadas seguintes. Os balanços produzidos nos anos 1990 foram predominantemente propostos por cientistas políticos e pela imprensa, no segundo caso em termos da enumeração dos aspectos "bons" e "maus" da ditadura (CARVALHO, CATELA, 2002, p. 217). O tema da ditadura, considerado demasiado recente, ainda era pouco visitado pelos profissionais da história. O Instituto de História do Tempo Presente francês, importante referência posterior, fora inaugurado em 1980 e o tempo presente ainda era considerado, mesmo nos países precursores desse campo disciplinar, interditado aos historiadores.

Duas obras publicadas em torno dos 30 anos do golpe, contudo, nos permitem identificar os debates historiográficos então travados, nos quais predominaram os temas das razões e da natureza do golpe. A primeira, de 1994, foi organizada pelos cientistas políticos Maria Celina D’Araújo e Gláucio Ary Dillon Soares (1994). O livro 21 anos de regime militar. Balanços e perspectivas propôs-se a pensar o legado do período autoritário com o distanciamento que permitia o tempo transcorrido de três décadas do golpe e quase uma década desde o retorno dos civis ao poder. Na orelha do livro, o historiador José Murilo de Carvalho menciona a complexidade de tratar o período, pela "carga emotiva derivada da intensidade do conflitos vividos por todos", especialmente entre os intelectuais, “vítimas principais da política de restrição à liberdade de expressão que marcou o regime" (SOARES, D’ARAÚJO, 1994). 
$\mathrm{Na}$ introdução, os organizadores ressaltam a preocupação em estabelecer uma análise desapaixonada do período, com critérios mais analíticos do que políticos. No tocante à natureza do regime, a especificidade do período é distinguida pelo evidente mando dos militares: "o país se defrontou com um governo inequivocamente controlado pelos militares" (SOARES, D’ARAÚJO, 1994, p. 2). Todavia, mencionam com destaque a "forte e consistente base civil" que lhe deu suporte, assentada nos setores empresariais e políticos que viram na aliança com os militares uma forma de conjurar o que viam como a ameaça comunista (SOARES, D'ARAÚJO, p. 3). A coletânea de textos privilegiou a análise da ditadura a partir de instituições: partidos políticos, sindicatos, forças armadas, empresariado, deixando de fora tanto a esquerda armada, quanto a repressão política.

Símbolo de uma corrente que teria amplificado desmedidamente o papel dos militares, em detrimento do componente civil, o artigo de Glácio Ary Dillon Soares sobre o golpe de 1964 foi provavelmente o que mais repercutiu nos debates historiográficos posteriores ${ }^{11}$. Sustentando sua argumentação nas narrativas castrenses sobre o golpe e a ditadura, Soares pretende reconstituir não apenas a variável política - segundo ele subestimada pela influência das explicações de teor economicista -, como o protagonismo dos militares como atores políticos. Defende que o golpe, independentemente do apoio de setores da elite civil, foi militar, assim como o regime que se seguiu (SOARES, 1994, p. 27). Nesse sentido, busca dar relevo em suas análises aos fenômenos diretamente ligados à caserna, como quebra da hierarquia e da disciplina, questões de promoção e a "infiltração comunista no meio militar", que teriam sido ignorados pela bibliografia a despeito de sua importância (SOARES, 1994, p. 31). Criticando autores que buscariam inferir o comportamento das forças armadas a partir de um esperado comportamento institucional ou classista, atenta para o "alto grau de especificidade dos militares", derivado de seu isolamento social, sistema próprio de valores, monopólio dos meios coercitivos, relativa autonomia institucional e fraco

\footnotetext{
${ }^{11} \mathrm{O}$ autor, juntamente com Maria Celina D’Araújo e Celso Castro, integrou ambicioso projeto desenvolvido no interior do Centro de Pesquisa de Documentação de História Contemporânea do Brasil (CPDOC) da Fundação Getúlio Vargas, de colher uma série de depoimentos de oficiais militares que tiveram papel importante em moldar a política do período ditatorial, sobretudo no que diz respeito ao seu aparelho repressivo. O projeto redundou na publicação de três volumes: Visões do Golpe, Os anos de chumbo e $A$ volta aos quarteis (D’ARAÚJO, SOARES, CASTRO, 1994a, 1994b, 1995).
} 
controle dos civis sobre eles. Em sua ânsia de complexificar o olhar sobre o fator militar, então pouco explorado em termos de visão concreta dos personagens envolvidos no golpe e na estruturação do regime, Soares acaba por destacá-los excessivamente, sem inseri-los nas tramas mais complexas da urdidura do golpe e sem fazer a devida crítica das fontes do discurso militar ${ }^{12}$.

A segunda publicação influente sobre os 30 anos do golpe foi produzida com a reunião de textos apresentados em evento realizado na UNICAMP, por ocasião do aniversário do golpe, mas publicado apenas em 1997 (TOLEDO, 2014 13). Um dos eixos da discordância dos autores está na questão do golpe e do "golpismo". O filósofo Caio Navarro de Toledo, organizador do livro, fala em termos de uma "Democracia populista golpeada", título de seu artigo. Aborda o crescente isolamento de João Goulart, fruto de sua política de gestos ambíguos, ora voltados para a esquerda, ora para os setores conservadores e o acirramento das tensões: "Nos meses seguintes [à tentativa do governo de aprovar um estado de sítio], uma pergunta passou a dominar a cena política: Quem dará o golpe?"14 (TOLEDO, 2014, p. 47). Toledo explica que a direita acreditava que seria Goulart, apoiado por setores nacionalistas, populares e da esquerda. Já os setores progressistas temiam a reação conservadora, ao mesmo tempo em que desconfiavam de Goulart. A função do golpe, concretamente perpetrado pelas elites, teria sido a de impedir um aprofundamento da democracia e, sua consequência, o estabelecimento de um "regime militar" que promoveria uma modernização conservadora, excludente e uma “ordem político-institucional crescentemente militarizadas” (TOLEDO, 2014, p. 56).

Gorender, na mesma obra, trata a questão do golpismo de uma maneira um pouco diferente: afirmando que estava presente à direita e à esquerda, entende a declaração de Luís Carlos Prestes em janeiro de 1964 sobre a necessidade de reformar a Constituição para permitir a reeleição de Jango como um "convite aberto ao golpe" (GORENDER,

\footnotetext{
${ }^{12}$ Outras obras de maior fôlego contribuiriam para aprofundar o argumento da importância dos militares e da influência de suas dinâmicas políticas internas na condução dos rumos políticos nacionais durante a ditadura (MARTINS FILHO, 1995; FICO, 2001; CHIRIO, 2012).

${ }^{13}$ A edição original é de 1997.

${ }^{14}$ (Em itálico no original.) Em publicação sobre o governo Jango, de 1982, da coleção Tudo é história, Toledo fala em termos de golpe "político-militar" e afirma "O governo João Goulart nasceu, conviveu e morreu sob o signo do golpe de Estado" (TOLEDO, 1991, p. 7).
} 
2014, p. 135). Curiosa essa interpretação de golpe para um intento de reforma constitucional... ${ }^{15} \mathrm{Em}$ termos dos contornos que assumiu o regime, Gorender aponta para as "grandes divergências entre os conspiradores", que não teriam por projeto instalar uma "ditadura militar".

Um terceiro posicionamento, ainda na mesma obra, que geraria bastante polêmica no decênio seguinte, foi o de Argelina Cheibub Figueiredo, autora do livro intitulado Democracia ou reformas? (1993). Debatendo com a bibliografia que explicava o golpe a partir de fatores de ordem econômico-estruturais e partindo dos diferentes atores e projetos políticos em conflito, a autora sustenta a tese segundo a qual "Nos anos 1960, [...] democracia e reformas eram percebidas como objetivos políticos conflitantes" (FIGUEIREDO, 2014, p. 60). O esforço das esquerdas não teria sido no sentido de expandir os limites de uma democracia liberal controlada pelas elites, porque essas possuíam tão pouco compromisso com o jogo democrático quanto a direta, "sempre pronta a romper com a democracia" para manter seus privilégios (FIGUEIREDO, 2014, p. 67). Assim, a defesa das reformas de base, que para Toledo e Gorender significavam um aprofundamento da democracia, para Figueiredo, por sua radicalidade, far-se-iam à custa da democracia.

A autora atribui o golpe à radicalização das posições dos atores políticos, que teria inviabilizado um compromisso, uma "solução negociada". Não confere, porém, o devido peso da escolha aos setores que efetivamente romperam o jogo institucional democrático. Falar em incompatibilidade das reformas desejadas com a democracia tem um desdobramento político controverso: o de que é necessário contentar-se com os estreitos limites da democracia liberal representativa para evitar que as elites instaurem regimes autoritários. Interessante notar que no início da introdução do livro em que desenvolve com maior complexidade seu argumento, a autora lembra que: "Uma questão clássica e ainda não resolvida da teoria democrática e das sociedades liberais é a tensão entre democracia política e desigualdade econômica e social" (FIGUEIREDO, 1993, p. 21). Depreende-se da proposição da autora que não há outra saída a não ser satisfazer-

\footnotetext{
${ }^{15}$ A pecha de "golpista" é tão desonrosa, que o bloco de direita que tomou de assalto o poder em 1964 denominou a intervenção como "revolução", pela legitimidade social que possuía o termo na época.
} 
se com mudanças reduzidas e graduais, ao risco de ver-se submetido a um regime autoritário. Em versão brasileira da teoria dos dois demônios, esquerda e bloco conservador são posicionados no mesmo patamar, como se as estratégias se equivalessem e como se os espaços institucionais de decisão política e de poder fossem igualmente franqueados aos representantes dos setores populares e das elites. Essa leitura, afinada com a expansão do neoliberalismo na América Latina dos anos 1990, sob o manto de uma interpretação distanciada e racional, tinha por efeito eliminar no presente a forte dose conflitiva da política, sob os auspícios da nova ordem mundial que se impunha no pós-Guerra Fria.

Se as teses que tendem a interpretar como equivalentes as disposições da esquerda e dos conservadores para tomar o poder foram formuladas nos anos 1990, foi nos anos 2000 que angariaram adeptos. As esquerdas brasileiras e latino-americanas adotavam uma postura mais conciliadora, voltando-se em peso à estratégia eleitoral como maneira de chegar ao poder. Um movimento que teve seus custos em termos da inserção dos partidos progressistas junto às bases de movimentos sociais comumente marginalizados, como os sem-terra, os diferentes grupos indígenas, os movimentos de atingidos por barragens, ou os sem-teto. Por outro lado, esses governos conduziram uma série de políticas de reparação e memória relacionadas à ditadura, um processo que coincidiu de forma notável com o crescimento, no âmbito acadêmico, de críticas às esquerdas dos anos 1960 e 1970, em particular à opção pela luta armada.

\section{4: 40 anos do golpe}

Os 40 anos do golpe mobilizaram a sociedade brasileira de diversas maneiras. Universidades promoveram debates, mesas-redondas e seminários, nos quais estudantes e pesquisadores dividiram as plateias com ex-militantes políticos. Entidades sindicais e culturais organizaram eventos em torno da data. Os meios de comunicação publicaram reportagens, encartes especiais e entrevistas com atores da época. O mercado editorial lançou livros acadêmicos e de memórias. 
No debate público, além de especialistas no período e ex-militantes de esquerda, estiveram presentes militares da reserva organizados em grupos de pressão formados nos anos 1990, assemelhados na interpretação das pautas relacionadas à Justiça de Transição como "revanchismo" e inconformados com o espaço ocupado por ex-presos políticos na política nacional (SANTOS, ALVES, 2014). O Clube Militar, por exemplo, entrou na "batalha de memórias" em 1996, quando o general Hélio Ibiapina assumiu sua presidência. Sites e blogs foram constituídos nessa mesma década, em reação ao início dos trabalhos da Comissão Especial sobre Mortos e Desaparecidos (CEMDP), como o Grupo Inconfidência e o Ternuma (RODRIGUES e VASCONCELOS, 2014).

Foram múltiplos os fatores que contribuíram para o crescimento do interesse público no tema. Na academia, a distância temporal, a abertura e disponibilização de arquivos - como os das Delegacias de Ordem Política e Social, do Projeto Brasil: Nunca Mais ou o arquivo Ana Lagoa - e o paulatino desenvolvimento da área de História do Tempo Presente favoreceram a expansão do campo. Novelas, filmes, documentários, peças teatrais, publicação de depoimentos, na área cultural e as políticas públicas voltadas à reparação de vítimas colaboraram igualmente a fazer aumentar a curiosidade sobre esse passado recente. Teve papel importante, ainda, a eleição em 2002 do sindicalista, líder das greves do $A B C$ nos anos 1980 e dirigente do Partido dos Trabalhadores (PT), Luís Inácio Lula da Silva.

Se, em 1998, Jacob Gorender em versão revisada e ampliada de O combate nas trevas notava a mudança do tratamento dos membros da esquerda armada de "terroristas" ou "bandidos" para o honroso desígnio de "guerrilheiros", Caio Navarro de Toledo, em 2004, comentava que a grande imprensa brasileira - outrora apoiadora do golpe e complacente com a ditadura -, trocara a expressão empregada pelos militares e os setores golpistas de "Revolução"16, para a de "golpe de Estado". Também notou a ausência de comemoração militar do aniversário do golpe, bem como as expressões públicas do comandante do Exército, em Ordem do Dia para os quartéis. Citou ainda o

\footnotetext{
${ }^{16}$ Curioso notar que o Dicionário Histórico Biográfico Brasileiro, editado pelo CPDOC/FGV pela primeira vez em 1984, mesmo em atualizações posteriores manteve o título "Revolução de 1964" do verbete escrito por Maurício Dias. Ao problematizar o emprego das duas expressões, "revolução" ou "golpe", conclui sobre a inadequação de ambos, caracterizando o processo como uma "reação conservadora".
} 
artigo do então ministro da Defesa em artigo no jornal Folha de S.Paulo exaltando a democracia e referindo-se ao passado como "página virada", cujas feridas não deveriam mais sangrar (TOLEDO, 2004, p. 30-1) . $^{17}$ O editorial do jornal paulista, seguia no mesmo tom:

Se há algo a comemorar no aniversário de 40 anos do golpe de 31 de março de 1964 é justamente o fato de podermos afirmar que o ciclo militar se encontra hoje encerrado num passado histórico. Se suas repercussões ainda se fazem sentir e se há facetas a merecer esclarecimentos, não há dúvida de que o fantasma da ditadura militar já não mais assombra a vida nacional (40 ANOS, 2004).

Embora fosse essa a posição oficial e institucional o Exército, o general Carlos de Meira Mattos, na mesma edição do jornal pretendeu oferecer a "verdadeira significação" do "movimento de 31 de março", que teria sido "uma necessidade inarredável para a sociedade brasileira", acossada por uma "minoria instalada no poder, que pregava abertamente a supressão do regime constitucional e a implantação de um sistema de governo fechado, opressivo" (MATTOS, 2004). Entrevistado pelo mesmo jornal, o exministro do Exército Leônidas Pires Gonçalves declarou: "A revolução salvou o Brasil de ser um Cubão, mas essas coisas têm um preço." O general segue queixando-se que “Ficam batendo nessa história de tortura e morte", argumentando que isso teria ocorrido dos dois lados: "Era uma guerra” (Apud MELO, 2004).

Essa visão, contudo, era minoritária. A lua-de-mel com uma democracia que parecia ter relegado a ditadura ao passado e expandia as possibilidades da construção de uma sociedade menos desigual, apontadas na eleição de um presidente progressista de origem operária, ampliou a tendência dos anos 1990 de tomar a democracia como palco e horizonte das transformações políticas. Na América Latina viviam-se os anos da chamada “onda rosa”, ciclo de presidentes de esquerda, iniciado com a eleição de Hugo Chávez na Venezuela em $1998^{18}$. A vitória pela via eleitoral implicava, por outro lado, certa moderação da agenda de esquerda e composição com outras forças políticas: a chegada ao governo estava longe de significar a tomada do poder pela via revolucionária.

\footnotetext{
${ }^{17} \mathrm{O}$ autor alerta, contudo, que "seria uma conclusão apressada, temerária e desmesurada acreditar que o conjunto da Corporação militar hoje renegue a 'Revolução de 1964"” (TOLEDO, 2004b, p. 30).

18 "Three-quarters of South America's 350 million people are now ruled by left-leaning presidents, all of whom have been elected in the last six years" (BBC, 2005).
} 
Nessa quadratura, um dos pontos-chave do debate historiográfico foi o tema da relação das esquerdas com a democracia, seja na conjuntura que levou ao golpe de 1964, seja na atuação dos grupos da esquerda armada. Na obra O golpe e a ditadura militar 40 anos depois (REIS, RIDENTI, MOTTA, 2004), reunindo falas de seminários acadêmicos ocorridos em São Paulo, Belo Horizonte e Rio de Janeiro ${ }^{19}$, Daniel Aarão Reis denunciava as "artimanhas da memória" que "traiçoeira", teria apagado a radicalização das esquerdas, que ressurgiam como "vítimas bem intencionadas, atingidas e perseguidas pelo movimento golpista" (REIS, 2004, p. 29). Não se tratava apenas de relembrar o caráter revolucionário dos projetos de setores da esquerda, já ressaltado por outros autores (GORENDER, 1998; RIDENTI, 1993), mas de denunciar sua "falta de compromisso" com a democracia. Embora Aarão Reis não poupe em seus textos críticas às distorções da memória produzidas também pelo campo da direita, parece demonstrar maior preocupação com a estigmatização dos militares golpistas, que na época receberam a pecha de "gorilas" (REIS, 2004, p. 40).

O artigo ecoava em tom mais polêmico ideias expostas em obra ensaística publicada em 2000, na qual discutia, entre outros temas, o apoio civil à ditadura. No ensaio está presente outra vertente desse debate, que diz respeito à memória sobre o caráter da luta da esquerda armada. A esquerda que optou pelo enfrentamento direto, para Daniel Aarão Reis, operara durante a transição um “deslocamento de sentido" (REIS, 2000, p. 70), transformando o combate por ideais revolucionários durante a ditadura em "resistência democrática" ao autoritarismo - ou seja, transfigurando o que fora um projeto ofensivo em prática defensiva. Denise Rollemberg, em texto publicado na coletânea sobre o Brasil republicano, endossa a ideia de que a memória dos anos 1960 e 1970 foi construída em função dos valores que orientavam os militantes políticos na década de 1980, banindo o tema da revolução: “Fica, então, a pergunta: por que a dificuldade de enfrentar a luta armada como uma opção das esquerdas?" (ROLLEMBERG, 2003, p. 49). A resposta sugerida refere-se ao isolamento que essa opção política gerou, já que a sociedade não acompanhou as vanguardas políticas que pretendiam realizar uma

\footnotetext{
${ }^{19}$ O evento no Rio de Janeiro foi "40 Anos do Golpe: 1964/2004", organizado pelo CPDOC/FGV, em parceria com a UFRJ e a UFF, de 22 a 26 de março de 2004. Em São Paulo, "1954-1964-2004: O golpe, memória e atualidade", organizado pela USP em parceria com a UNICAMP, de 9 a 12 de novembro de 2004.
} 
ruptura radical com a ordem capitalista. A autora relaciona a dificuldade em assumir esse insulamento e seus significados - tema que entretanto aparece em uma série de depoimentos reproduzidos no livro de Marcelo Ridenti (1993), publicado nos anos 1990 à interpretação segundo a qual sua origem seria consequência da repressão política. Embora compartilhe fundamentalmente das teses de Aarão Reis ${ }^{20}$, há que se registrar que Rollemberg adota uma narrativa que permite compreender que "os valores democráticos não estruturavam a sociedade brasileira", que o Brasil vivera diferentes tentativas golpistas por parte dos setores conservadores e que a esquerda revolucionária via a democracia como "burguesa, liberal, parte de um sistema que se queria derrubar" (ROLLEMBERG, 2003, p. 48).

Retomando a discussão sobre o "golpismo" que marcou os 30 anos, Jorge Ferreira, em obra sobre o Brasil Republicano, adotou as teses de Argelina Figueiredo, investindo na teoria dos dois demônios à brasileira: "Entre a radicalização da esquerda e da direita, uma parcela ampla da população apenas assistia aos conflitos, silenciosa" (FERREIRA, 2003, p. 400)². Marco Antônio Villa, na biografia Jango: um perfil (1945-1964), bateu na mesma tecla:

A crise de 1961 acabou fortalecendo a democracia como valor fundamental da República. [...] Três anos depois, a democracia foi considerada, pela maior parte dos contendores, um entulho de uma velha ordem, numa curiosa metamorfose: de valor universal, passou a ser considerada obstáculo para o bom exercício do governo (VILLA, 2004, p. 240).

Em artigo que discute as polêmicas em torno dos 40 anos do golpe, Caio Navarro de Toledo reflete sobre como os autores dessa linha de interpretação, que chama de “revisionista”22, “contribuíram para levar 'água para o moinho’ dos ideólogos que ainda

\footnotetext{
${ }^{20}$ Interessante notar que nesse texto de 2003, Denise Rollemberg já usa o termo "ditadura civil-militar" (p. 49), ao passo que em 2004, Daniel Aarão ainda usava o termo "ditadura militar", embora se referisse ao golpe como "movimento civil-militar". Em obra organizada por Daniel Aarão Reis e Jorge Ferreira (2007), o termo "civil-militar" aparece em subtítulo, mas não é reivindicado teoricamente.

${ }^{21}$ Convém assinalar que na década seguinte, Ferreira mudaria sua interpretação: "É importante observar que não houve da parte do presidente, nem das esquerdas qualquer iniciativa que possa ser definida como 'golpista"' (FERREIRA, 2015).

${ }^{22}$ Aarão Reis assume a classificação, embora queixe-se do tom pejorativo do termo (JOFFILY, SCHLATTER, 2011, p. 246).
} 
justificam o movimento político-militar de 1964" (TOLEDO, 2004, p. 34). Cita declarações publicadas na imprensa dos militares Jarbas Passarinho e Meira Matos e do jornalista Ruy Mesquita, membro da família detentora dos direitos sobre o jornal O Estado de S.Paulo, que falam em "contragolpe preventivo". Ainda que reconheça "parcelas de responsabilidades [das esquerdas] no agravamento e radicalização do processo político que culminou no golpe de Estado" (TOLEDO, 2004, p. 43), argumenta, com razão, que os defensores da teoria dos "dois golpes” não distinguem motivações, atuações concretas, capacidade de ação e meios materiais dos diversos grupos envolvidos no pré-1964, igualando responsabilidades que são de teor absolutamente distinto (TOLEDO, 2004, p. 34, 43-3). Ademais, quem efetivamente deflagrou o golpe foram os setores da elite.

Jornais de grande circulação tornaram-se palco para as disputas historiográficas, tendência que amplificar-se-ia nos 50 anos de 1964. Interessante notar o uso da fala de historiadores como "especialistas do tema", para legitimar posições não exatamente coincidentes com as das empresas de comunicação. A Folha de S.Paulo, por exemplo, defendeu a tese dos “vários planos de golpe" (Apud D’ÁVILA, 2004). A ressalva de Carlos Fico sobre a ausência de evidência empírica de que João Goulart planejava uma saída inconstitucional é minimizada pela noção de que, entre os diversos planos intervencionistas, "vingou" o da direita.

A tese de que o termo "resistência democrática" na realidade encobria, em parte, a luta revolucionária radical também foi alvo de atenção da imprensa:

Um dogma precioso aos adversários da ditadura militar iniciada a 31 de março de 1964 está em xeque. Novos estudos realizados por especialistas no período [referência a Daniel Aarão Reis e Denise Rollemberg] - alguns deles integrantes dos grupos de oposição ao regime autoritário - propõem uma mudança explosiva, que semeia fúria nos defensores de outras correntes: chamar de resistência democrática a luta da esquerda armada na fase mais dura do regime está errado, historicamente falando (MOTTA, OTAVIO, LAMEGO, 2004, p. 8).

A matéria d'O Globo é peça particularmente ilustrativa das relações entre história, mídia e debates políticos relacionados à história do tempo presente. Embora cubra uma polêmica que, com contornos menos definidos, remontava aos anos 1990, apresenta o 

atacando uma "crença”. Apesar de exibir vozes discordantes sobre uma interpretação em disputa, o artigo apresenta as posições historiográficas que não endossa como um "erro".

Entre os historiadores citados no artigo que se contrapuseram à versão defendida pelo jornal, houve duas vertentes. Renato Lemos concorda com o caráter revolucionário das lutas da esquerda e considera "responsabilidade ética, social, política e histórica da esquerda assumir suas ideias e ações durante a ditadura". Porém não o faz com o tom de denúncia de Aarão Reis, e sim de reivindicação de uma escolha política válida no contexto em que foi assumida. Essa diferença não deve ser menosprezada, porque marca justamente o posicionamento político dos dois autores diante da luta armada: a de rotundo equívoco, para Aarão Reis, e a de opção plausível no contexto histórico referido, ainda que derrotada, para Lemos. Marcelo Ridenti e Maria Aparecida de Aquino argumentam em sentido um pouco distinto: as organizações de esquerda armada promoveram sim resistência à ditadura militar, embora não tenha sido democrática.

Vale lembrar que se o conteúdo democrático do projeto revolucionário, em sintonia com diversos grupos da esquerda latino-americana e europeia na época, pode ser problematizado, no Brasil ou no exílio, diversos ex-integrantes dos grupos de esquerda armada ingressaram no movimento oposicionista que pressionou pela transição democrática. Além disso, naquele momento histórico, a revolução dera espaço para outras preocupações políticas imediatas: apontar as responsabilidades da ditadura e seu aparato repressivo, buscar informações sobre o paradeiro dos desaparecidos políticos, punir os responsáveis, ter acesso aos documentos da repressão. Esse movimento foi bem identificado por Maria Paula Araújo:

"A derrota da luta armada propiciou a construção de um novo campo de luta e oposição ao regime. Esse novo campo buscava romper os limites da clandestinidade e tornar visível a oposição à ditadura. Dessa forma valorizava a luta política e legal e a participação em espaços públicos e abertos. Uma oposição cada vez mais legal, pública, visível e até mesmo 
institucional começou a se delinear a partir dos primeiros anos da década de 1970, logo após a derrota da luta armada, entre 1972 e 1974. Em 1974 esse novo quadro já estava com os contornos claramente definidos" (2000, p. 118).

Em artigo sobre os 40 anos do golpe, Marcelo Ridente reflete sobre os desdobramentos políticos do embate, em termos do usos das falas dos acadêmicos para legitimar visões que nem sequer coincidiam com o que estava sendo sustentado. Comenta que a matéria do Globo mencionada foi de pronto reproduzida no site do Exército, cuja posição oficial nunca foi de rechaço ao golpe e à ditadura. Ressalta ainda que a narrativa jornalística constrói duas análises alheias à fala de todos os entrevistados: a noção de que o golpe justificou-se por ter combatido setores revolucionários antidemocráticos e a ideia de que a sociedade esteve alheia ao combate de dois extremos. Analisando as implicações no debate político público da apropriação dos debates historiográficos, indaga:

Pode-se questionar se o resultado final de certa interpretação historiográfica não gera uma incorporação política contrária à intenção original: ao invés de questionar a suposta isenção de amplos setores da sociedade civil em relação à ditadura, dá argumentos para reforçar a ideologia que isenta esses setores de cumplicidade com o regime, e até o justifica (RIDENTI, 2004, p. 60) ${ }^{23}$.

O tema é delicado porque toca em pontos nevrálgicos da História do Tempo Presente: a consciência do campo político em que elaboramos nossas produções acadêmicas e no qual serão apropriadas por outros atores, com ou sem nosso consentimento; os usos (e abusos) políticos do passado e nossa possível contribuição, ainda que involuntária, a versões das quais discordamos.

Em meio às controvérsias, dois sentidos consolidaram-se na historiografia dos anos 2004: o golpe foi perpetrado por uma ampla aliança civil-militar e o que se instalou a partir de 1964 foi uma ditadura. Jacob Gorender, em artigo para a revista Tendências e

\footnotetext{
${ }^{23}$ Ridenti refere-se a outra polêmica trazida pela obra de Daniel Aarão Reis, publicada em 2000, a de que a sociedade brasileira, embora tivesse construído uma memória de rechaço à ditadura, teria aderido à mesma de diversas formas, dando-Ihe suporte (REIS, 2000, p. 66). Esse tema, de presença ainda discreta em 2004, seguida da defesa de uma caracterização da ditadura como “civil-militar”, seria um dos pontos nodais dos debates dos 50 anos do golpe, em 2014.
} 
debates faz uma mea culpa em relação ao emprego da expressão "golpe militar": "O que chamamos de golpe militar teve inequívoco e poderoso apoio social”. Acrescenta: "A sociedade estava nitidamente cindida. Irritada pelas numerosas greves, pela carestia, pelo desabastecimento de gêneros alimentícios e pela inoperância oficial, a classe média se passou maciçamente para o campo dos opositores do governo Jango" (GORENDER, 2004). Vale lembrar que esse aspecto já fora apontado pelos expoentes das primeira narrativas. Esse apoio, porém, não aparece como adesão espontânea e convicta de setores médios. Em Dreifuss, é resultado de campanha coordenada pela elite burguesa, com vistas a "manipular a opinião pública", e usar a classe média como "massa de manobra" da elite (1981, p. 281). No BNM, como consequência do convencimento de setores médios e populares pela propaganda anticomunista (ARQUIDIOCESE DE SÃO PAULO, 1985, p. 59).

A importância que assumiu o apoio civil ao golpe na historiografia, pode ser identificada em dois trabalhos de Carlos Fico. Em Como eles agiam, publicado em 2001, a despeito de mencionar o apoio inicial de expressivos setores da classe média urbana, bem com de políticos civis, defende que o golpe foi um movimento "indubitavelmente militar" (FICO, 2001, p. 20). Em 2004, porém, revê essa posição: "Se podemos falar de um golpe civil-militar, trata-se, contudo, da implantação de um regime militar — em duas palavras: de uma ditadura militar" (FICO, 2004b, p. 52).

O tema dos apoios civis de setores da sociedade brasileira, não apenas no golpe, mas ao longo da ditadura e sua importância na definição dos rumos políticos do período, também foi apresentado nos 40 anos. Esse questionamento, proposto em 2000 por Aarão Reis, inspirado pelas historiografias russa sobre o stalinismo, alemã sobre a cumplicidade de setores da sociedade com o nazismo e francesa sobre Vichy, buscou explicar a longevidade da ditadura, impossível sem alguma base de sustentação social, e os traços autoritários disseminados na sociedade brasileira. A população civil aparece nessa discussão não apenas como a elite condutora do golpe, ou como sua "massa de manobra" e sim como atores oriundos das classes médias e populares que aderiram voluntariamente à ditadura e a apoiaram mesmo em práticas autoritárias. Abriu-se, nesse 
momento, uma nova linha de investigação, ensejando um debate que assumiria grandes proporções na década seguinte.

A popularização do termo "ditadura", substituindo o termo genericamente utilizado de "regime militar", foi efetuada não por um historiador, mas por um jornalista. Entre 2002 e 2004 Elio Gaspari lançou quatro obras, todas com o termo no título. A expressão fora utilizada pelo sociólogo Florestan Fernandes (1982), porém era empregada parcimoniosamente pela bibliografia, que na maioria das vezes lançava mão preferencialmente da expressão "regime militar", mais neutra do ponto de vista político. Depois das obras do conhecido jornalista liberal, contudo, houve uma generalização do termo "ditadura" e "regime militar" assumiu ares de expressão conceitualmente imprecisa e politicamente insípida ${ }^{24}$.

A obra de Gaspari ${ }^{25}$ (2002a, 2002b, 2003, 2004, 2016) contribuiu a difundir o interesse pelo tema entre uma classe média não acadêmica, mas recebeu duras críticas. Em primeiro lugar, por não disponibilizar então ao acesso público, os acervos exclusivos dos quais se serviu, os arquivos privado de Golbery do Couto e Silva e de Heitor Ferreira. Em seguida, por nem sempre fazer rigorosa crítica das fontes, ou tomar a devida distância dos protagonistas a partir dos quais conta a história da ditadura e dos quais por vezes adota a perspectiva: Golbery e Ernesto Geisel. Do ponto de vista historiográfico, apontase um desprezo para questões estruturais de ordem econômica e social, peso desmedido aos militares e, sobretudo, uma história centrada no perfil psicológico de alguns atores (FICO, 2004; RAMPINELLI, 2005; BADARÓ, 2008). Gaspari alinhou-se à teoria dos dois golpes em curso: "A árvore do regime estava caindo, tratava-se de empurrá-la para a direita ou para a esquerda" (2002, p. 52) e reforçou uma narrativa liberal, descrita com competência por Marcos Napolitano:

\footnotetext{
24 Interessante que o mesmo autor refere-se aos membros da esquerda armada como "terroristas", justificando sua escolha pela leitura de textos de Carlos Marighella, no que não foi acompanhado por nenhum outro autor, a não ser pelos ativistas de ultradireita adeptos do período autoritário.

${ }^{25}$ São cinco volumes (GASPARI, 2002a, 2002b, 2003, 2004, 2016).
} 
a) o golpe foi um acontecimento fortuito, sem projeto ou conspiração eficazes, produzido pela incompetência política de João Goulart; b) os conspiradores civis, inocentes úteis, foram progressivamente alijados do novo regime ou romperam com ele, ao perceberem o endurecimento político progressivo; c) havia um núcleo liberal no Exército que foi neutralizado pela "linha dura", entre 1967 e 1974 e obrigado por ela a aceitar medidas de violência política e d) a pressão dos quartéis estaria na base do endurecimento do regime, portanto, este processo não seria fruto de uma estratégia política. Nessa tradição de análise, a responsabilidade dos civis e militares "liberais" que foram artífices do golpe e do regime fica atenuada, pois eles teriam perdido o controle do processo político, abrindo espaço para a violência política da "ditadura escancarada" de 1968 a 1974 (NAPOLITANO, 2004, p. 196).

A periodização sugerida por Gaspari ${ }^{26}$ abriria caminho para um debate que firmarse-ia apenas na década seguinte, dividindo o período entre uma "ditadura temporária" exercida por Castello Branco entre 1964 e 1967, um sistema constitucional de 1967 a 1968, uma ditadura "escancarada" de 1968 a 1974 e a saída da ditadura de 1974 a 1979. Assim, a ditadura, para Gaspari, deve medir-se essencialmente pelo uso da tortura por agentes do Estado (2002a, p. 129) ${ }^{27}$. Note-se que a periodização, como no livro de Daniel Aarão Reis (2000), termina em 1979 e não no marco clássico de 1985, quando houve a passagem da presidência das mãos dos militares aos civis. Prenúncios de um debate em torno da cronologia da ditadura que afloraria nos 50 anos do golpe.

\section{4: 50 anos do golpe}

Os 50 anos do golpe foram debatidos com grande intensidade, tendo sido o ápice de um conjunto de políticas de memória, que culminou com os trabalhos da CNV, combinados com a efeméride de meio século e seu apelo editorial. O período destacou-se igualmente por uma maior polarização entre setores de esquerda e direita, como resultado das sucessivas administrações do Partido dos Trabalhadores, maior pluralidade de vozes e atores, e a disputa eleitoral à presidência da República. Um dos fenômenos interessantes, foi que os ex-militantes políticos deixaram de ocupar apenas as plateias, como na década anterior, e passaram a compor as mesas de debates, ao lado de

\footnotetext{
${ }^{26}$ Quem chamou a atenção para esse aspecto foi Valdir Rampinelli (2005).

${ }^{27}$ Em 2016 um novo volume, A ditadura acabada, seria publicado, cobrindo os anos finais do governo militar.
} 
pesquisadores do tema, sinal de sua legitimação social como atores e testemunhas do período. No meio acadêmico, as polêmicas com forte conotação política foram diversas, havendo ampliação significativa dos temas de pesquisa e uma enxurrada de publicações sobre 1964. Dos debates que nos ocupam, destaco três, fortemente interconectados: um já antigo, sobre o caráter civil-militar ou militar da ditadura; um desdobramento dessa questão, incidindo sobre as relações entre a sociedade civil e o governo militar; outro mais recente, embora já anunciado em algumas obras, em torno da periodização.

Entre as políticas públicas envolvendo a memória da ditadura, podemos citar aquelas voltadas a acervos, como a transferência de documentos de órgãos extintos ao Arquivo Nacional, em novembro de 2005, ou a criação, em 2009, do Centro de Referências das Lutas Políticas do Brasil (1964-1985) - Memórias Reveladas, com o intuito de disponibilizar ao público vasto acervo documental sobre a ditadura militar. A Lei de Acesso à Informação (n. 12.527), aprovada em novembro de 2011, foi um marco no acesso à documentação sobre o período. As Caravanas da Anistia, mobilizadas em diversos pontos do país pela Comissão de Anistia a partir de 2008, também contribuíram para trazer atenção pública ao tema da ditadura, oferecendo espaço público de escuta a pessoas que sofreram perseguição política.

Tentativas de reverter a impunidade de agentes do Estado que praticaram torturas e assassinatos ajudaram a manter o tema aceso. A Ordem dos Advogados do Brasil requereu ao Supremo Tribunal Federal um posicionamento sobre a interpretação da Lei de Anistia de 1979, alegando que os agentes repressivos teriam cometido crimes comuns e não políticos - já que estes seriam restritos àqueles contrários à segurança nacional e à ordem política e social (STF, 2008). O Ministério Público Federal em São Paulo abriu uma Ação Civil Pública contra dois oficiais do exército envolvidos na repressão política. Em 2012, o MPF constituiu um grupo de trabalho de Justiça de Transição, baseado no entendimento da imprescritibilidade do desaparecimento forçado, do sequestro e ocultação de cadáver (MPF, 2017). Houve ainda o estabelecimento de memoriais e monumentos públicos, bem como iniciativas de rever a nomenclatura de logradouros públicos que homenageavam nomes relacionados à ditadura militar. 
A posse de uma ex-guerrilheira, Dilma Rousseff, em janeiro de 2011 e a promulgação da lei que criava a CNV no final desse mesmo ano colaboraram enormemente para que a ditadura ocupasse de forma ostensiva o debate público. A atuação da CNV, acompanhada por suas congêneres estaduais, municipais e setoriais deram lugar à fala de diversos perseguidos pela ditadura e constituíram espaço de diálogo - por vezes conflituoso - com familiares de desaparecidos e de ex-presos políticos $^{28}$ (FRANCO, 2017; BAUER, 2017). As audiências realizadas nessas esferas também expuseram as versões de agentes do Estado envolvidos na repressão política, oferecendo uma polifonia de vozes a respeito da memória social do período (CHIRIO, JOFFILY, 2016).

Reavivou-se com grande intensidade a guerra das memórias. As Forças Armadas, acompanhadas de antigos ministros do Estado e do Supremo Tribunal Militar, pronunciaram-se em manifesto contra os trabalhos da CNV e recusaram-se a pedir desculpas à nação pelas violações aos direitos humanos cometidas no período em que estiveram no poder (ARAÚJO, KAPA, 2014) ${ }^{29}$. Na reação aos intentos de responsabilizar agentes de Estado envolvidos na repressão política e à criação da CNV, ex-membros da Comunidade de Informações editaram, em 2012, o livro Orvil, resposta ao projeto Brasil: nunca mais, elaborado nos anos 1980 pela Seção de Informações do Centro de Informações do Exército e arquivado, na época, em nome da conciliação (GRAHAL, $2016)^{30}$.

2014 foi ao mesmo tempo o ápice da discussão pública sobre a ditadura e o início de uma derrocada política que levaria ao golpe de 2016. Altamente simbólica foi a diferença entre a pompa da cerimônia de criação da CNV, em 2012, com a presença de todos os ex-presidentes vivos pós-ditadura, assinalando uma política de Estado de revisão do passado recente e a tímida entrega do relatório final, dois anos depois. Entre uma e outra, o nebuloso ano de 2013, com suas manifestações de rua de conteúdo político disperso e contraditório. Esse foi o ano também da curiosa autocrítica do jornal O Globo, alegadamente uma resposta ao "clamor das ruas", que acusava a empresa de

\footnotetext{
${ }^{28}$ Sobre a importância dos familiares de desaparecidos políticos na transição democrática, ver (TELES, 2013).

29 "Jamais aprovamos qualquer ofensa à dignidade humana", dizem generais em manifesto (OESP, 2014).

${ }^{30}$ É significativo, porém, que a publicação não tenha sido oficialmente referendada pelo Exército.
} 
ocorrido em um contexto de grande radicalização política e do "temor de um outro golpe, a ser desfechado pelo presidente João Goulart, com amplo apoio dos sindicatos" (APOIO, 2013).

A CNV, constituída majoritariamente por profissionais da área do Direito, deu pouco espaço para os historiadores, embora tenha contado com uma bibliografia por eles construída ao longo de décadas. Criada para reconciliar e não julgar, como aponta Motta (2013, p. 67), ao mesmo tempo em que construía pela primeira vez uma narrativa oficial do Estado de crítica global da ditadura, no que foi seguida por uma série de comissões em outros âmbitos, gerou forte reação de grupos de direita saudosos da ditadura. Se a existência desses grupos não era novidade, a expansão de uma direita que não teme assumir-se como tal é inédita no cenário político do Brasil pós-ditadura, surpreendendo com a adesão conquistada entre segmentos mais jovens e com disposição de ocupar as mídias e as ruas. Assim, na década de 2010 vivemos uma configuração política que ecoa traços da experiência vivida nos anos 1960: diante do crescimento das forças de esquerda, o conservadorismo brasileiro mostra seus dentes. Discursos da extrema direita antes recolhidos a determinados nichos, passaram a expandir sua área de atuação, difundindo o mote moralista da anticorrupção, o conservadorismo católico incrementado com o enorme crescimento das igrejas evangélicas - e a defesa das Forças Armadas como instituição capaz de reconduzir a política aos seus trilhos.

As políticas de reparação e de memória que tornaram discurso "oficial” a crítica à ditadura militar não tocaram no essencial dos acordos de transição controlada para a democracia: o poder de veto das Forças Armadas, a existência das Polícias Militares e a punição dos agentes repressivos. Porém, aliadas ao esforço de inclusão social promovidas pelos governos do PT, provocaram fissuras profundas na hegemonia da memória liberal sobre a ditadura (NAPOLITANO, 2015). Isso porque não se tratava mais simplesmente de discurso, mas de propor mudanças - ainda que em muitos planos superficiais - na abrangência concreta da democracia brasileira. 
O jornal Folha de S.Paulo, em editorial de fevereiro de 2009 falando da política do presidente venezuelano Hugo Chávez, referiu-se à ditadura brasileira como "ditabranda" (FSP, 2009). O posicionamento suscitou diversas reações, inclusive do editor do caderno Brasil do próprio jornal, Fernando de Barros e Silva:

O mundo mudou um bocado, mas "ditabranda" é demais. O argumento de que, comparada a outras instaladas na América Latina, a ditadura brasileira apresentou níveis baixos de violência política e institucional parece servir, hoje, para atenuar a percepção dos danos daquele regime de exceção, e não para compreendê-lo melhor (Barros, 2009).

De fato, o movimento de relativização do peso da ditadura recebeu chancela acadêmica com Marco Antônio Villa que, como outros autores, ocupou o espaço da grande imprensa para anunciar sua interpretação sobre o período. Um dos grandes debates foi o da periodização da ditadura que, segundo Villa, não teria durado 21 anos: “Não é possível chamar de ditadura o período 1964-1968 (até o Al-5), com toda a movimentação político-cultural. Muito menos os anos 1979-1985, com a aprovação da Lei de Anistia e as eleições para os governos estaduais em 1982". A ditadura "à brasileira", defendeu o autor, ecoando o editorial da Folha de S.Paulo, teria sido mais amena que suas congêneres no Cone Sul e a memória do caráter "retrógrado e repressivo do regime" teria sido construído por intelectuais que se beneficiaram de "generosas aposentadorias" ${ }^{31}$ (VILLA, 2009).

No aniversário de 48 anos do golpe, em 2012, Daniel Aarão Reis, em artigo publicado pelo jornal O Globo, acusou de "preguiça mental” àqueles que chamam a ditadura de "militar" e defendeu 1979 como seu marco final, pois o estado de exceção ter-se-ia encerrado com o fim da vigência do Al-5 e com a Lei da Anistia. Entre 1979 e 1985, teria vigorado um Estado autoritário - e não propriamente uma ditadura -, ocupado em gerir a transição para a democracia. Seu argumento repousa no fato de que o ano tradicionalmente considerado como o do final do regime autoritário, marca a passagem do mandato presidencial de um militar para um civil, após eleições indiretas. Porém, o político que viria a ocupar o posto, José Sarney, foi um dos principais apoiadores civis da

\footnotetext{
${ }^{31}$ Provavelmente alusão a indenizações oferecidas pelo governo a perseguidos políticos.
} 

tinha se oposto a ele (REIS, 2012).

Renato Lemos, contra-atacou em carta enviada ao Globo, demonstrando a fina linha que separa a historiografia da memória social: "Por que entender a expressão 'ditadura militar' como produto da memória e não, também e principalmente, de um conhecimento construído de acordo com premissas teórico-ideológicas sistemáticas?” (LEMOS, 2012). Lembrou, por outro lado, que se a denominação "ditadura militar" beneficiava os setores civis que apoiaram a ditadura e depois quiseram distanciar-se da imagem do regime pela memória negativa socialmente estabelecida, o termo "ditadura civil-militar" também tinha o inconveniente político de legitimar o argumento dos militares golpistas de que haviam ocupado o poder em resposta a uma demanda da sociedade civil. Lemos chama ainda a atenção para quais segmentos civis teriam sido os principais beneficiários da modernização autoritária do país e contesta o paradoxo apontado por Aarão Reis de que os "anos de chumbo" - referindo-se ao momento de maior repressão política - teriam sido ao mesmo tempo "anos de ouro" - alusão ao “milagre econômico". "Falso paradoxo", afirma Lemos, "Há farta evidência de que o 'milagre brasileiro' - a fábrica do 'ouro' desses anos - custou à esmagadora maioria da classe trabalhadora o ‘chumbo' do arrocho salarial, dos serviços públicos degradados e outras mazelas [...]" (LEMOS, 2012). Por fim, sustenta que, ao falar em uma sociedade civil desvinculada de seus pertencimentos de classe e categoria sociais, Aarão Reis estaria promovendo uma mistificação da história, justamente o que afirmava combater. Essa posição é referendada por outros autores marxistas, como Demian Bezerra de Melo, que dentro da via aberta por Dreifuss, defende a necessidade de atentar para os setores que se beneficiaram com as políticas promovidas pela ditadura: a despolitização da sociedade, a desarticulação dos movimentos sociais organizados e enorme concentração de renda. Assim, uma denominação mais precisa seria a de ditadura "empresarial-militar" (MELO, 2014, p. 16). 
Sobre a periodização, vale notar dois elementos. O primeiro é a comparação dessas às interpretações de Villa e de Aarão Reis, que reduzem os marcos da ditadura, com as políticas de memória já mencionadas, baseadas em recortes cronológicos consideravelmente mais amplos. A Lei dos Desaparecidos (1995) vai de setembro de 1961 a outubro de 1988; o dossiê da Comissão Especial sobre Mortos e Desaparecidos Políticos, publicado em 2007, pela Secretaria dos Direitos Humanos, começa em $1961^{32}$ e segue até 1985; as leis de criação da Comissão de Anistia (2002) e a da criação da CNV (2011) operam ambas com o intervalo de tempo transcorrido entre as constituições de 1946 e de 1988, o que foi alvo de acerbas críticas, já que descaracterizava o período ditatorial. Em comum, o confronto com a periodização tradicional de 1964-1985. O segundo ponto é que a argumentação de Aarão Reis seria consideravelmente mais convincente, para quem adota a perspectiva da "ditadura civil-militar", caso a proposta fosse não abreviar o período, mas usar como marco final o ano de 1988, com a promulgação da nova Constituição.

Aqueles que sustentam que o golpe foi deflagrado por uma ampla coalizão civilmilitar, mas que a ditadura foi militar, argumentam que do ponto de vista da dinâmica do regime e da condução política concreta, a decisão esteve em última instância na mão dos militares (MARTINS FILHO, 2014; FICO, 2014; NAPOLITANO, 2014). João Martins Filho, em particular, sustenta que malgrado a inegável participação civil, no que diz respeito à ideologia do regime, ao gerenciamento das crises políticas ao longo do período, à militarização da sociedade e à estrutura do poder, o regime foi essencialmente militar (MARTINS FILHO, 2014). Quanto ao tema da periodização, lembra que o ritmo e a forma de transição para a democracia, mesmo após 1979, foi controlada pelos militares. Carlos Fico segue a mesma direção: "não é o apoio político que determina a natureza dos eventos da história, mas a efetiva participação dos agentes históricos em sua configuração." Nesse sentido, recorda, como já havia feito em sua obra de 2001, que

\footnotetext{
${ }^{32}$ Prevaleceu o entendimento de que a ordem constitucional brasileira já havia sido rompida em setembro desse ano, quando houve uma tentativa por parte dos militares de impedir a posse do do vicepresidente João Goulart, após a renúncia de Jânio Quadros (CEMDP, 2007, p. 51).
} 
Aarão Reis, manteve sua linha de denúncia das "zonas de sombra" da memória sobre os pontos de sustentação do regime na sociedade civil, que teria erigido "heróis da resistência, os verdadeiros e os fictícios que pouco ou nada teriam a ganhar com a melhor compreensão do período" (REIS, 2014, p. 26). Marcos Napolitano traz importante contribuição ao debate ao assinalar que essa memória hegemônica não foi construída, como insinua Aarão Reis, pela esquerda, que teria aberto mão de seus projetos revolucionários em troca de uma postura democrática que lhe desse espaço de integração política no processo de abertura. Para Napolitano, embora tivesse incorporado em parte visões da esquerda - armada e não armada - essa memória, na realidade, foi essencialmente uma construção "liberal conservadora": "Ao elogiar a resistência em abstrato, e condenar as ações de alguns resistentes, em concreto (como os guerrilheiros), a memória liberal conseguiu, ardilosamente, apagar o papel dos liberais na construção da ordem autoritária" (NAPOLITANO, 2015, p. 19-20).

Sem desconsiderar arranjos e ambiguidades, Marcelo Ridenti (2014) evita cair em explicações que apoiam-se excessivamente seja na "cumplicidade" da população com o regime, seja em seu papel opositor. Argumenta que "modernização, desenvolvimento capitalista, autoritarismo e lutas sociais" conviveram de maneira complexa e conflituosa. Nesse quadro multifacetado, aponta para a divisão da esquerda brasileira e seu papel de oposição clandestina, o distanciamento de setores de classe média que apoiaram o golpe mas foram adotando uma postura crítica ao regime, devido à recessão econômica e ao crescente autoritarismo, as ambiguidades e oscilações entre colaboração e oposição de órgãos da sociedade civil, a retomada dos movimentos sociais no período da abertura. Argumenta ainda que, se por um lado a ditadura contou com a cooperação e adesão de setores da sociedade civil, por outro teve de ceder mais de uma vez às reivindicações de setores oposicionistas, como já identificara Maria Helena Moreira Alves (RIDENTI, 2014).

\footnotetext{
33 Em artigo publicado em 2017, Fico defende que Ernesto Geisel tinha um projeto delineado de transição para a democracia, e que "a saída do regime militar foi controlada pelos militares" (FICO, 2017, p. 66).
} 
Partidários da tese de que no golpe de 1964 não estava contida a ditadura que se seguiria, Jorge Ferreira e Ângela de Castro Gomes distinguem o que teria sido o apoio de amplos setores civis ao golpe e seu posicionamento posterior:

Quer dizer, aqueles que aplaudiam e festejavam a vitória da 'revolução pela ordem' não tinham como saber o que sucederia nos anos seguintes. Seus aplausos, naquele preciso momento, não devem ser confundidos com apoio a um regime autoritário, violento e ditatorial que perduraria até 1979, quando foi votada a lei da Anistia (FERREIRA, GOMES, 2014, p. 16).

Entre os autores que contribuíram para esse debate com pesquisas empíricas, Denise Rollemberg foi pioneira ${ }^{34}$. Examinou de forma detida o papel da Ordem dos Advogados do Brasil (OAB) e da Associação Brasileira de Imprensa ( $A B I)$, baseando-se em documentos das respectivas instituições e discutindo seus posicionamentos ao longo da ditadura. Concluiu, no caso da $\mathrm{ABI}$, que as posições entre apoio e rejeição conviviam na mesma entidade, mostrando sua ambivalência diante da ditadura (ROLLEMBERG, 2010). Quanto à $O A B$, mais homogênea em sua posição política, houve uma mudança de posicionamento, da colaboração ao enfrentamento, passando "de uma trincheira à outra" (ROLLEMBERG, 2008).

Discutindo o apoio da sociedade ao golpe e à ditadura por meio de pesquisas de opinião do Ibope, Rodrigo Patto Sá Motta chegou a uma posição semelhante à de Rollemberg: não se pode falar nem em termos adesão irrestrita, nem em oposição frontal à ditadura, mas em posições que variaram ao longo do período (MOTTA, 2014a, p. 21). Em obra sobre as políticas universitárias da ditadura, Motta mostrou a complexidade das relações entre a sociedade civil e a ditadura militar no processo de reforma universitária, na qual teriam prevalecido as ambiguidades e os “jogos de acomodação”. Estes teriam funcionado dos dois lados: tanto em concessões à política autoritária da ditadura por

\footnotetext{
34 Daniel Aarão Reis lançou o debate, mas de maneira ensaística. Orientou diversos trabalhos na linha historiográfica que propôs, porém não desenvolveu pesquisas próprias com fontes primárias. Em entrevista publicada em 2011, reconheceu que “Às vezes eu até emprego o termo 'sociedade brasileira' na polêmica, mas isso tem que ser bem qualificado. A sociedade brasileira é uma sociedade plural. [...] É claro que quando comecei essa polêmica, talvez não tenha ficado muito esclarecido, porque na polêmica você entra muito chamando a atenção para eu sou contra ou a favor" (JOFFILY, SCHLATTER, 2011, p. 250).
} 
parte das universidades, quanto de proteção por parte dessas instituições a intelectuais de esquerda, por seu talento acadêmico. A ditadura teria incorporado, na reforma do meio acadêmico, demandas sociais dos setores sociais derrotados com o golpe, embora o tenha feito de maneira autocrática e elitista (MOTTA, 2014, p. 8).

Usando como chave interpretativa o conceito de cultura política, o autor defende a tese de que na relação da ditadura militar com a sociedade operaram duas tendências de longa permanência na tradição política brasileira: a "conciliação" e a "acomodação", com vistas a evitar conflitos. Teriam prevalecido o favorecimento de laços particulares e arranjos informais em detrimento de relações impessoais e regras universais (MOTTA, 2014, p. 13). Conquanto lembre que a ditadura militar era "construção política considerada legítima por setores sociais significativos" (MOTTA, 2014b, p. 301), contorna a armadilha das generalizações em torno da resistência versus colaboração da sociedade civil, introduzindo noções mais matizadas de resistência, adesão e acomodação. Assim, por meio do estudo das universidades, chega a uma conclusão mais geral: “O Estado construído após o golpe de 1964 representou tentativa de conciliar demandas opostas, já que o caráter heterogêneo de sua base de apoio gerou pressões em direções contrárias" (MOTTA, 2014b, p. 15). Duas importantes ressalvas fazem sua análise mais precisa: a estratégia conciliatória costuma ser empregada quando se trata de membros da elite social e a acomodação buscada visa a manutenção do status quo, de exclusão política e enorme desigualdade social.

O conceito de "cultura política" deve ser usado com cuidado pelos historiadores sob o risco de cristalizar o que seriam os traços da tradição política brasileira. Na longa duração de nossa política prevalece, com efeito, uma tendência ao estabelecimento de acordos políticos pelo alto, combinando "moderno" e "arcaico", sem que as sólidas estruturas que mantêm a brutal desigualdade social sejam tocadas (RIDENTI, 2014). Entretanto, herança não é destino, por isso precisamos conhecer e debater o passado se quisermos ser capazes de superá-lo. 


\section{O golpe de 2016 mudará o golpe de 1964?}

O aumento do interesse público sobre a ditadura militar, contínuo e progressivo, desdobrou-se em farta produção acadêmica, acompanhando também a grande expansão da pós-graduação no Brasil a partir dos anos 1980. A multiplicidade de pesquisas monográficas deverá contribuir não apenas para dar nova feição aos debates historiográficos aqui tratados, como propor outros, fruto de novos questionamentos abertos pelo trabalho das diversas comissões da verdade, pelo recurso à grande quantidade e variedade dos acervos disponíveis e pelas transformações políticas vividas pelo país.

O golpe parlamentar - e também midiático e jurídico - sofrido pela presidenta Dilma Rousseff, em abril de 2016 suscitou uma série de comparações com o golpe de 1964. Guardadas as inúmeras diferenças entre os períodos históricos, o episódio, bem como a atuação da $C N V$, reestabeleceu uma série de conexões entre uma conjuntura que entre muitos gera incompreensão e perplexidade e um passado que não cessa de ser refeito com vistas a explicar o presente.

A discussão sobre o caráter militar ou civil-militar do golpe e da ditadura, iniciada nos anos 1980, assumiu diversas camadas de significado a partir da década de 2000, incorporando os apoios civis à ditadura - em termos de setores sociais e graus de adesão - e nos anos 2010 - ampliado para estudos mais focados sobre a definição de quais grupos sociais e quais os graus de colaboração, acomodação e resistência. Esse debate, cuja longevidade impressiona ${ }^{35}$, tende a ser retomado em um contexto em que o golpe contra os anseios reformistas populares ocorreu novamente, em 2016, por meio de uma aliança entre o Congresso, a grande mídia, empresários e o Judiciário, porém sem participação dos militares. Essa diferença poderá trazer pistas para refletir sobre o peso do fator militar na configuração do período 1964-1985.

Ao longo das décadas, complexificou-se também o estudo dos setores golpistas, na identificação de contradições, rivalidades e fissuras dentro dos grupos que de fato promoveram a queda de João Goulart e conduziram a política nacional. Esse movimento

\footnotetext{
${ }^{35}$ Ver por exemplo o recente debate entre o coletivo Zagaia e o jornalista Pedro Pomar (PAGLIARINI, 2017).
} 
tendeu a contrapor as primeiras interpretações sobre a existência prévia de um projeto bem acabado de reestruturação social e econômica do qual o golpe teria sido o gesto inaugural. Assim, militares - e no interior destes a comunidade de informações -, imprensa, Judiciário, universidades, associações profissionais, sindicatos, partidos políticos, Igreja receberam atenções concentradas que possibilitam uma visão mais contrastada e sofisticada do bloco de poder e suas redes de sustentação, mostrando fissuras, contradições e ambiguidades.

A conjuntura atual possivelmente estimule uma reflexão referente à atuação das esquerdas nos anos 1960, à luz da experiência de governo dos anos 2000 e suas consequências posteriores no Brasil e na América Latina. O debate sobre os limites da democracia liberal, em particular em um país com histórica concentração de renda e intolerância à participação popular nas esferas de decisão, bem como a respeito da tradição golpista das elites brasileiras, deve merecer atenção tanto de pesquisadores consagrados, quanto das novas gerações. A memória da ditadura como período de exceção, para o qual nos voltamos ao denunciar autoritarismos e arbitrariedades, tende nesse momento a ser repensada, com vistas a apreciar a ditadura como mais um episódio de uma longa tradição de exclusão social e política de setores populares.

Há conjunturas nas quais as pontes com determinados momentos históricos são reabertas, estabelecendo como mandato a inquirição das experiências passadas na busca de dar inteligibilidade ao presente. A premência política e social de certos debates posiciona a história no centro de um campo extremamente disputado, para o qual confluem interesses acadêmicos, políticos, midiáticos e sociais. Não por acaso, como vimos, ao longo dessas últimas décadas, a grande imprensa tornou-se palco de difusão e discussão de interpretações historiográficas sobre a ditadura militar, conforme políticas de memória e debates públicos remetiam a essa temática.

A interlocução com um público mais amplo abre espaço para uma bem-vinda inserção dos historiadores no espaço público, uma das características intrínsecas à História do Tempo Presente. Porém, ao mesmo tempo, pode acarretar em simplificações que corroboram à construção de mitos, contribuindo com usos e abusos do passado, na contramão dos valores mais caros ao nosso campo profissional. As exigências éticas - 
sempre presentes no trabalho do historiador - multiplicam-se no entroncamento com as esferas do social e do político, requerendo uma difícil negociação entre 1. nosso compromisso com os rigores da pesquisa histórica e sua complexidade; 2. nossa contribuição como historiadores e cidadãos na construção e difusão de um saber regido por regras próprias, em um espaço altamente conflitivo; e 3. a consciência do estatuto de legitimidade acadêmica e científica socialmente atribuído ao nosso ofício.

\section{Referências}

"JAMAIS aprovamos qualquer ofensa à dignidade humana", dizem generais em manifesto. O Estado de S.Paulo, 26 set. 2014.

40 ANOS depois. Folha de S.Paulo, 31 mar. 2004.

ALVES, Maria Helena Moreira. Estado e oposição no Brasil (1964-1984). Petrópolis: Vozes, 1984 .

APOIO editorial ao golpe de 64 foi um erro. O Globo, 31 ago. 2013.

ARAÚJO, Maria Paula. A Utopia fragmentada: as novas esquerdas no Brasil e no mundo na década de 1970. Rio de Janeiro: FGV, 2000.

ARAÚJO, Vera; KAPA, Raphael. Anos de chumbo: general contesta ministro e diz que não haverá pedido de desculpas. O Globo. 23 set. 2014.

ARQUIDIOCESE DE SÃO PAULO. Brasil: Nunca Mais. Petrópolis: Vozes, 1985.

BADARÓ, Marcelo Mattos. O governo João Goulart: novos rumos da produção historiográfica. Revista Brasileira de História. São Paulo, v. 28, n. 55, p. 245-263, 2008.

BARROS, Fernando de. Ditadura, por favor. Folha de S.Paulo, 24 fev. 2009.

BAUER, Caroline Silveira. Como será o passado? Jundiaí: Paco Editorial, 2017.

BBC. South America's leftward sweep. 2 mar. 2005. Disponível em:

http://news.bbc.co.uk/2/hi/americas/4311957.stm. Acesso em: out. 2017. 
BENEVIDES, Maria Victória. 64, um golpe de classe?, Lua Nova, n. 58, 2003, p. 255-262.

CARVALHO, Alessandra; CATELA, Ludimila da Silva. 31 de Marzo de 1964 en Brasil. In: JELIN, Elizabeth (Org.). Las conmemoraciones: las disputas en las fechas "in-felices". Buenos Aires: Siglo Veintuno, 2002, p. 195-244.

CHIRIO, Maud; JOFFILY, Mariana. La verdad de los verdugos. Las comparecencias de los agentes de la represión ante la Comissão Nacional da Verdade de Brasil. Rubrica

Contemporanea, v. 5, n. 9, 2016, p. 11-33.

CHIRIO, Maud. A política nos quartéis. Rio de Janeiro: Jorge Zahar, 2012.

COMISSÃO ESPECIAL SOBRE MORTOS E DESAPARECIDOS POLÍTICOS (CEMDP), Direito à verdade e à memória. Brasília: Secretaria Especial de Direitos Humanos, 2007.

D’ARAÚJO, Maria Celina; SOARES, Gláucio Ari Dillon; CASTRO, Celso (Org.). Visões do golpe. Rio de Janeiro: Relume-Dumará, 1994a.

D’ARAÚJO, Maria Celina; SOARES, Gláucio Ari Dillon; CASTRO, Celso (Org.). Os anos de chumbo. Rio de Janeiro: Relume Dumará, 1994b.

D’ARAÚJO, Maria Celina; SOARES, Gláucio Ari Dillon; CASTRO, Celso (Org.). A volta aos quartéis. Rio de Janeiro: Relume Dumará, 1995.

D’ARAÚJO, Maria Celina. Taking Stock (with discomfort) of the Military Dictatorship Fifty Years after the 1964 Coup: a Bibliographical Essay. Bras. Political Sci. Rev. Vol. 9, n. 3, p.143-163, 2015.

D’ÁVILA, Sérgio. O dia em que os militares tomaram o poder. Folha de S.Paulo, 31 mar. 2004 .

DREIFUSS, René Armand. 1964, a conquista do Estado. Petrópolis: Vozes, 1981.

FERNANDES, Florestan. A ditadura em questão. São Paulo: T.A. Queiroz, 1982.

FERREIRA, Jorge; GOMES, Ângela de Castro. 0 golpe que derrubou um presidente, pôs fim ao regime democrático e instituiu a ditadura no Brasil. Rio de Janeiro: Civilização Brasileira, 2014.

FERREIRA, Jorge; REIS, Daniel Aarão. Revolução e democracia 1964... Rio de Janeiro: Civilização Brasileira, 2007. 
FERREIRA, Jorge. O golpe faz 50 anos. In: ALONSO, Ângela; DOLHNIKOFF, Míriam (Orgs.). 1964, do golpe à democracia. São Paulo: Hedra, 2015, p. 43-69.

FERREIRA, Jorge. O governo Goulart e o golpe civil-militar de 1964. In. FERREIRA, Jorge; DELGADO, Lucilia de Almeida Neves (Orgs). O Brasil republicano. Rio de Janeiro: Civilização Brasileira, 2003, Livro 3, p. 343-404.

FICO, Carlos. Além do golpe. São Paulo: Record, 2004a.

FICO, Carlos. Como eles agiam. Rio de Janeiro: Record, 2001.

FICO, Carlos. Ditadura militar brasileira: aproximações teóricas e historiográficas. Tempo e Argumento, Florianópolis, v. 9, n. 20, jan.-abr. 2017, p. 5 -74.

FICO, Carlos. $O$ golpe de 1964. Momentos decisivos. Rio de Janeiro: FGV, 2014.

FICO, Carlos. Versões e controvérsias sobre 1964 e a ditadura militar. In: Revista Brasileira de História. 2004b, vol. 24, n. 47, p. 29-60.

FIGUEIREDO, Argelina Cheibub, Democracia ou reformas?: Alternativas democráticas à crise política, 1961-1964. Rio de Janeiro: Paz e Terra, 1993.

FIGUEIREDO, Argelina Cheibub, Democracia \& reformas: A conciliação frustrada. In: TOLEDO, Caio Navarro de (Org.). 1964: visões críticas do golpe. Campinas: EdUnicamp, 2014, p. 59-68.

FRANCO, Paula. A escuta que produz a fala: o lugar do gênero nas comissões estaduais e na Comissão Nacional da Verdade (2011-2015). (Dissertação, mestrado em História). UDESC, Florianópolis, 2017.

GASPARI, Elio. A ditadura acabada. Rio de Janeiro: Intrínseca, 2016.

GASPARI, Elio. A ditadura derrotada. São Paulo: Companhia das Letras, 2003.

GASPARI, Elio. A ditadura encurralada. São Paulo: Companhia das Letras, 2004.

GASPARI, Elio. A ditadura envergonhada. São Paulo: Companhia das Letras, 2002a.

GASPARI, Elio. A ditadura escancarada. São Paulo: Companhia das Letras, 2002b.

GORENDER, Jacob. A sociedade cindida. Teoria \& Debate, n. 57, mar.-abr., Fundação Perseu Abramo, 2004. 
GORENDER, Jacob. Combate nas trevas. São Paulo: Ática, 5 a edição, 1998.

GORENDER, Jacob. Era o golpe de 1964 inevitável? In: TOLEDO, Caio Navarro de (Org.). 1964: visões críticas do golpe. Campinas: EdUnicamp, 2014, p. 133-142.

GRAHAL, Clarissa. Das armas às letras: os militares e a constituição de um campo memorialístico de defesa à ditadura empresarial-militar. (Dissertação, mestrado em História). UFSC, 2016.

JELIN, Elizabeth (Org.). Las conmemoraciones: las disputas en las fechas "in-felices". Buenos Aires: Siglo Veintuno, 2002.

JOFFILY, Mariana; SCHLATTER, Sérgio Luis. Entrevista com Daniel Aarão Reis. Tempo e Argumento. Florianópolis, v. 3, n. 1, p. 239 - 255, jan/jun. 2011.

LEMOS, Renato A “ditadura civil-militar” e a reinvenção da roda historiográfica. Carta enviada ao jornal O Globo, 2012. Disponível em:

http://www.ifcs.ufrj.br/ lemp/imagens/textos/A_dita dura_civil-

militar_e_a_reinvencao_da_roda_historiografica.pdf. Acesso em: dez. 2012.

LIMITES a Chavez. Folha de S.Paulo, 17 fev. 2009.

MARTINS FILHO, João Roberto. A guerra da memória: a ditadura militar nos depoimentos de militares e militantes. Vária História, Belo Horizonte, n. 28, p. 178-201, 2003.

MARTINS FILHO, João Roberto. Adieu à la dictature militaire?. Brésil(s). Sciences humaines et sociales, $n^{\circ}$, maio, 2014, p. 17-32.

MARTINS FILHO, João Roberto. O palácio e a caserna. São Carlos: EdUFSCar, 1995.

MATTOS, Carlos de Meira. O 31 de março de 1964. Folha de S.Paulo, 31 mar. 2004.

MELO, Demian Bezerra de. (Org.). A miséria da historiografia: uma crítica ao revisionismo contemporâneo. Rio de Janeiro: Consequência, 2014.

MELO, Murilo Fiuza de. Polarização de 64 persiste nas interpretações atuais. Folha de S.Paulo, 31 mar. 2004.

MINISTÉRIO PÚBLICO FEDERAL. Crimes da Ditadura. Brasília: MPF, 2017.

MOTTA, Aydano André; OTÁVIO, Chico; LAMEGO, Cláudia. Resistência democrática, dogma que desaba. O Globo, 20 mar. 2004. 
MOTTA, Rodrigo Patto Sá. As universidades e o regime militar. Rio de Janeiro: Zahar, 2014b.

MOTTA, Rodrigo Patto Sá. História, memória e as disputas pela representação do passado recente. Patrimônio e Memória, v. 9, p. 56-70, 2013.

MOTTA, Rodrigo Patto Sá. O golpe de 1964 e a ditadura nas pesquisas de opinião. Tempo, 2014, v. 10, p. 1-21.

NAPOLITANO, Marcos. 1964: história do regime militar brasileiro. São Paulo: Contexto, 2014.

NAPOLITANO, Marcos. Historiografia, memória e história do regime militar brasileiro. Resenha. Revista de Sociologia Política, Curitiba, 23, nov. 2004, p. 193-6.

NAPOLITANO, Marcos. O golpe de 64 e o regime militar brasileiro: apontamentos para uma revisão bibliográfica. Contemporanea, v. 2, p. 208-217, 2011.

NAPOLITANO, Marcos. Recordar é vencer: as dinâmicas e vicissitudes da construção da memória sobre o regime militar brasileiro. Antíteses. V. 8, n. 15 esp., nov. 2015, p. 9-44.

NAPOLITANO, Marcos. Roteiro de leituras para o estudo do golpe civil-militar de 1964. In: Guia bibliográfico da FFLCH. São Paulo: FFLCH/USP, 2016.

PAGLIARINI, André. “De onde? Para onde?” The continuity question and the debate over Brail's "civil”-military dictatorship. Latin American Research Review. 52(5), p. 760-774, 2017.

PIZA, Daniel. Nos livros, os muito golpes. O Estado de S.Paulo, 31 mar. 2004.

RAMPINELLI, Waldir José. Uma obra grande com grande lacunas. Resenha. Proj. História, São Paulo, v. 31, p. 419-426, dez. 2005.

REIS, Daniel Aarão; RIDENTI, Marcelo; MOTTA, Rodrigo Patto Sá (orgs.). O golpe e a ditadura militar - 40 anos depois (1964- 2004). Bauru: Edusc, 2004.

REIS, Daniel Aarão. A revolução faltou ao encontro. Os comunistas no Brasil. São Paulo: Brasiliense, 1990.

REIS, Daniel Aarão. Ditadura militar, esquerdas e sociedade. Rio de Janeiro: Jorge Zahar, 2000. 
REIS, Daniel Aarão. A ditadura civil-militar. O Globo, 31 mar. 2012.

REIS, Daniel Aarão. Ditadura e sociedade, as reconstruções da memória. In: RIDENTI, Marcelo; MOTTA, Rodrigo Patto Sá (orgs.). 0 golpe e a ditadura militar - 40 anos depois (1964- 2004). Bauru: Edusc, 2004, p. 29-52.

REIS, Daniel Aarão. Modernização, ditadura e democracia. 1960-2010, Rio de Janeiro: Objetiva; Madri: Fundación Mapfre, 2014.

RIDENTI, Marcelo. As oposições à ditadura: resistência e integração. In: REIS, Daniel Aarão; ; MOTTA, Rodrigo Patto Sá. A ditadura que mudou o Brasil. Rio de Janeiro: Zahar, 2014, p. 30-47.

RIDENTI, Marcelo. O fantasma da Revolução Brasileira. São Paulo: EdUnesp, 1993.

RIDENTI, Marcelo. Resistência e mistificação da resistência armada contra a ditadura. In. REIS, Daniel Aarão; RIDENTI, Marcelo; MOTTA, Rodrigo Patto Sá (Orgs.). 0 golpe e a ditadura militar - 40 anos depois (1964- 2004). Bauru: Edusc, 2004.

RODRIGUES, Fernando da Silva e VASCONCELOS, Cláudio Beserra. Os oficiais brasileiros da reserva e a defesa da memória institucional do "31 de março de 1964". História Unisinos. 18(3), p. 514-528, set.-dez. 2014

ROLLEMBERG, Denise. As Trincheiras da Memória. A Associação Brasileira de Imprensa e a ditadura (1964-1974). In: ; Quadrat, Samantha Viz (orgs.). A construção social dos regimes autoritários: legitimidade, consenso e consentimento no século XX. Rio de Janeiro, Civilização Brasileira, 2010.

ROLLEMBERG, Denise. Esquecimento das memórias. João Roberto Martins Filho (org.). 0 golpe de 1964 e o regime militar. São Carlos: Ed. UFSCar, 2006, p. 81-91.

ROLLEMBERG, Denise. Esquerdas revolucionárias e luta armada. In: FERREIRA, Jorge. $O$ governo Goulart e o golpe civil-militar de 1964. In. Jorge Ferreira; Lucilia de Almeida Neves Delgado (Orgs). O Brasil republicano: o tempo da experiência democrática. Rio de Janeiro: Civilização Brasileira, 2003, Livro 3, p. 43-92.

ROLLEMBERG, Denise. Memória, Opinião e Cultura Política. A Ordem dos Advogados do Brasil sob a Ditadura (1964-1974). IN: REIS, Daniel Aarão; ROLLAND, Denis. (Orgs.).

Modernidades Alternativas. Rio de Janeiro: FGV, 2008, p. 57-96

SANTOS, Eduardo Heleno de Jesus e ALVES, Vágner Camilo. Os grupos de pressão formados por militares da reserva e o pensamento anticomunista. Mediações, Londrina, V. 19, n. 1, p. 135-150, jan.jun. 2014. 
SILVA, Fernando de Barros e. Ditadura, por favor. Folha de S. Paulo, 24 fev. 2009.

SILVEIRA, Rosa. Resenha. Revista de História. FFLCH, Universidade de São Paulo, n. 117, p. $187-191$.

SOARES, Gláucio Ary Dillon; D’ARAÚJO, Maria Celina (Orgs.). 21 anos de regime militar. Rio de Janeiro: FGV, 1994.

SOARES, Gláucio Ary Dillon. O golpe de 64. In: ; D’ARAÚJO, Maria Celina (Orgs.). 21 anos de regime militar. Rio de Janeiro: FGV, 1994, p. 9-51.

STEPAN, Alfred. The military in politics. Princenton: Princeton University Press, 1971.

SUPREMO TRIBUNAL FEDERAL (STF). OAB contesta Lei da Anistia para crimes cometidos em nome do Estado. 21 out. 2008. Disponível em:

http://www.stf.jus.br/portal/cms/verNoticiaDetalhe.asp?idConteudo=98024. Acesso em: nov. 2017.

TELES, Janaína Almeida. A atuação dos familiares de mortos e desaparecidos políticos na transição democrática brasileira. In: PIMENTEL, Irene Flunser; REZOLA, Maria Inácia. (Org.). Democracia, Ditadura, Memória e Justiça Política. Lisboa: Tinta da China, 2013, p. 43-66.

TOLEDO, Caio Navarro de. 1964: Golpismo e democracia. As falácias do revisionismo. In: Crítica Marxista, 2004, p. 27-48.

TOLEDO, Caio Navarro de. 1964: visões críticas do golpe. Campinas: EdUnicamp, 2014.

TOLEDO, Caio Navarro de. 0 governo Goulart e o golpe de 64. São Paulo: Brasiliense, $11^{\text {a }}$ edição, 1991.

VILLA, Marco Antônio. Ditadura à brasileira, Folha de S.Paulo, 5 mar. 2009.

VILLA, Marco Antônio. Jango, um perfil (1945-1964). São Paulo: Globo, 2004. 
Recebido em 15/12/2017 Aprovado em 28/02/2018

Universidade do Estado de Santa Catarina - UDESC Programa de Pós-Graduação em História - PPGH

Revista Tempo e Argumento Volume 10 - Número 23 - Ano 2018 tempoeargumento@gmail.com 